This is the final peer-reviewed accepted manuscript of:

Michela Rosini, Elena Simoni, Roberta Caporaso, Filippo Basagni, Michele Catanzaro, Izuddin F. Abu, Francesca Fagiani, Federica Fusco, Sara Masuzzo, Diego Albani, Cristina Lanni, lan R. Mellor, Anna Minarini., Merging memantine and ferulic acid to probe connections between NMDA receptors, oxidative stress and amyloid- $\beta$ peptide in Alzheimer's disease, European Journal of Medicinal Chemistry, Volume 180, 2019,Pages $111-120$.

The final published version is available online at: https://doi.org/10.1016/j.ejmech.2019.07.011

Rights / License:

The terms and conditions for the reuse of this version of the manuscript are specified in the publishing policy. For all terms of use and more information see the publisher's website.

This item was downloaded from IRIS Università di Bologna (https://cris.unibo.it/)

When citing, please refer to the published version. 
Research paper

\title{
Merging memantine and ferulic acid to probe connections between NMDA receptors, oxidative stress and amyloid- $\beta$ peptide in Alzheimer's disease
}

\author{
Michela Rosini ${ }^{\text {a, * }}$, Elena Simoni ${ }^{\text {a }}$, Roberta Caporaso ${ }^{a}$, Filippo Basagni ${ }^{a}$, Michele Catanzaro ${ }^{\text {b }}$, Izuddin F. Abu ${ }^{\text {c, d }}$, \\ Francesca Fagiani ${ }^{\text {be e }}$, Federica Fusco ${ }^{\mathrm{f}}$, Sara Masuzzo ${ }^{\mathrm{f}}$, Diego Albani ${ }^{\mathrm{f}}$, Cristina Lanni ${ }^{\mathrm{b}}$, Ian R. Mellor ${ }^{\mathrm{c}}$, \\ Anna Minarini ${ }^{\mathrm{a}, * *}$ \\ a Department of Pharmacy and Biotechnology, Alma Mater Studiorum - University of Bologna, Via Belmeloro 6, 40126, Bologna, Italy \\ ${ }^{\mathrm{b}}$ Department of Drug Sciences (Pharmacology Section), University of Pavia, V.le Taramelli 14, 27100, Pavia, Italy \\ ${ }^{c}$ School of Life Sciences, University of Nottingham, University Park, Nottingham, NG7 2RD, UK \\ ${ }^{d}$ Universiti Kuala Lumpur, Institute of Medical Science Technology, A1-1, Jalan TKS1, Taman Kajang Sentral, 43000, Kajang, Selangor, Malaysia \\ e Scuola Universitaria Superiore IUSS Pavia, P.zza Vittoria, 15, 27100, Pavia, Italy \\ ${ }_{\mathrm{f}}^{\mathrm{f}}$ Department of Neuroscience, Istituto di Ricerche Farmacologiche Mario Negri IRCCS, Via Mario Negri 2, 20156, Milan, Italy
}

\section{A R T ICLE INFO}

Article history:

Received 10 June 2019

Received in revised form 2 July 2019

Accepted 3 July 2019

Available online $\mathrm{xxx}$

Keywords:

Memantine

Ferulic acid

NMDA receptors

Oxidative stress

Amyloid- $\beta$ peptide

\begin{abstract}
A B S T R A C T
N-methyl-D-aspartate receptors (NMDAR) are critically involved in the pathogenesis of Alzheimer's disease (AD). Acting as an open-channel blocker, the anti-AD drug memantine preferentially targets NMDAR overactivation, which has been proposed to trigger neurotoxic events mediated by amyloid $\beta$ peptide $(\mathrm{A} \beta)$ and oxidative stress. In this study, we applied a multifunctional approach by conjugating memantine to ferulic acid, which is known to protect the brain from $A \beta$ neurotoxicity and neuronal death caused by ROS. The most interesting compound (7) behaved, like memantine, as a voltage-dependent antagonist of NMDAR $\left(\mathrm{IC}_{50}=6.9 \mu \mathrm{M}\right)$. In addition, at $10 \mu \mathrm{M}$ concentration, 7 exerted antioxidant properties both directly and indirectly through the activation of the Nrf-2 pathway in SH-SY5Y cells. At the same concentration, differently from the parent compounds memantine and ferulic acid alone, it was able to modulate $\mathrm{A} \beta$ production, as revealed by the observed increase of the non-amyloidogenic sAPP $\alpha$ in H4-sw cells. These findings suggest that compound 7 may represent a promising tool for investigating NMDAR-mediated neurotoxic events involving A $\beta$ burden and oxidative damage.
\end{abstract}

(C) 2019.

\section{Introduction}

Synaptic loss is a major feature in Alzheimer's disease (AD). This chronic neurodegenerative condition, which is currently afflicting about 47 million people worldwide, slowly destroys neurons leading to progressive cognitive disabilities [1]. How synapses are affected in

\footnotetext{
Abbreviations: AD, Alzheimer's disease; ANOVA, analysis of variance; APP, amyloid precursor protein; A $\beta$, amyloid $\beta$ peptide; DCFH-DA, dichlorodihydrofluorescein diacetate; eNMDAR, extrasynaptic NMDAR; FA, ferulic acid; fl-APP, full-length APP; H4-sw, APP-Swedish mutant-expressing H4 cell lines; HO-1, heme oxygenase-1; MEM, memantine; MTT, 3-(4,5-dimethylthiazol-2-yl)-2,5-diphenyl-tetrazolium bromide; NMDAR, N-methyl-D-aspartate receptors; Nrf2, nuclear factor (erythroid-derived 2)-like 2; Ppm, parts per millions; sAPP $\alpha$, soluble amyloid precursor protein $\alpha$; SDS, sodium dodecyl sulfate; sNMDAR, synaptic NMDAR; TMS, tetramethylsilane

* Corresponding author.

** Corresponding author.

Email addresses: michela.rosini@unibo.it (M. Rosini); anna.minarini@unibo.it (A. Minarini)
}

the disease process remains unclear. The mechanistic understanding of synaptic damage represents a challenging goal, and may offer new possibilities for the prevention and cure of the disease. N-methyl-D-aspartate receptors (NMDAR) are ionotropic glutamate receptors known to play an important role for synaptic plasticity in the healthy brain [2]. They are primarily involved in neuronal excitatory synaptic transmission that underlies learning and memory but also in excitotoxic damage occurring during acute brain injuries and chronic neurodegenerative conditions. Targeting NMDAR therapeutically is therefore complicated by the dichotomous nature of their downstream signaling. It is the common view that these opposite effects depend on receptor localization: activation of synaptic NMDAR (sNMDAR) may contribute to cell survival and plasticity, while activation of extrasynaptic NMDAR (eNMDAR) may preferentially signal to neuronal death $[3,4]$. In particular, overactivation of eNMDAR has been associated with glutamate-mediated oxidative damage potentially leading to aberrant, misfolded proteins [5]. The amyloid $\beta$ peptide $(\mathrm{A} \beta)$ is a pathogenic feature of $\mathrm{AD}$ development. Produced by the sequential cleavage of the amyloid precursor protein (APP) by $\beta$ - and $\gamma$-secretases, as an alternative to the non-amy- 
loidogenic cleavage performed by $\alpha$-secretase, A $\beta$ monomers aggregate into soluble oligomeric forms, which are believed to be mainly responsible for amyloid-driven synaptotoxicity [6]. A toxic positive feedback is established between $\mathrm{A} \beta$ production and eNMDAR overactivation, which involves cytoplasmic $\mathrm{Ca}^{2+}$ upregulation and aberrant redox-mediated reactions [7].

Memantine is an anti-AD drug currently in use for the treatment of moderate-to-severe forms of the disease. It is an uncompetitive/fast off-rate NMDAR antagonist. By acting as an open-channel blocker, it preferentially enters the channel's pore in conditions of excessive and prolonged glutamate exposure [8,9]. Its favorable kinetics has been proposed to selectively direct memantine's efficacy toward extrasynaptic/tonically-activated NMDAR over synaptic/phasically-activated NMDAR [10], accounting for the clinical tolerability of the drug. Further, this peculiar profile seems to play a crucial role in de-

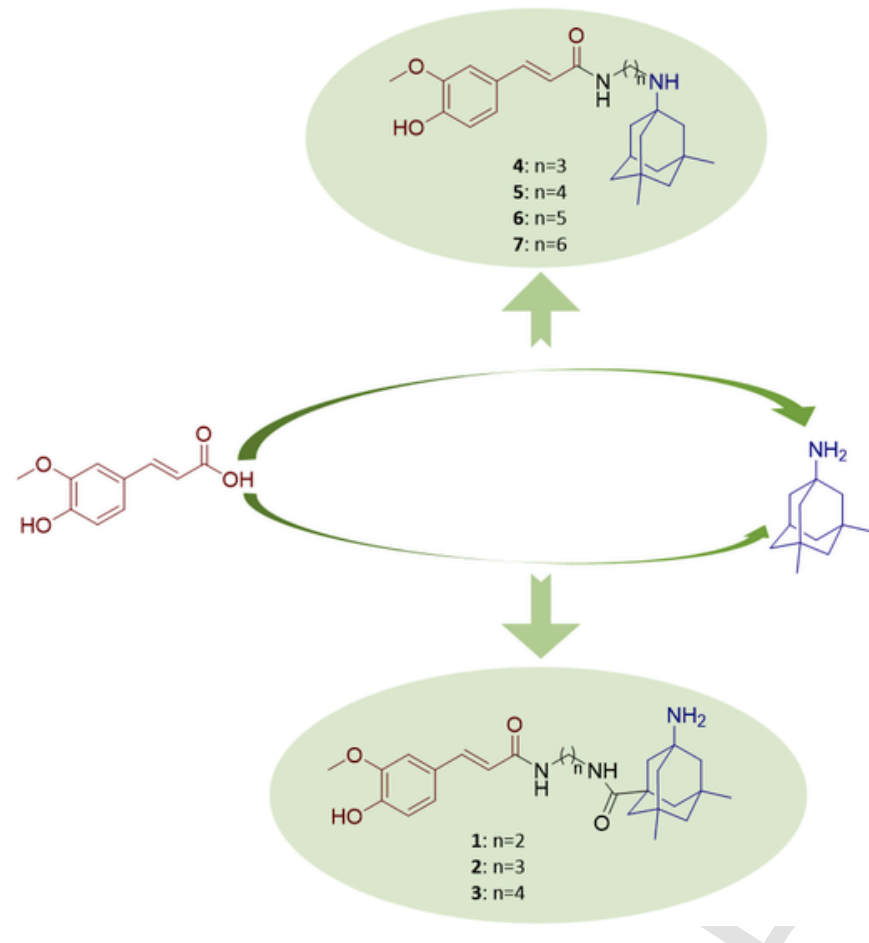

Fig. 1. Drug design of compounds 1-7. termining memantine's ability to alleviate $A \beta$-induced synaptic dysfunction and to rescue both neuronal oxidative stress and the transient memory impairment caused by $\mathrm{A} \beta$ oligomers [11]. Unfortunately, however, like other available anti-AD drugs, memantine offers only a symptomatic relief to patients and is not able to halt the disease progression.

Based on these premises, we sought to combine in a single molecule memantine, which specifically modulates NMDAR-mediated excitotoxicity, responsible for ROS- and A $\beta$-mediated neurotoxic events, with the antioxidant ferulic acid (FA), whose well-established biological properties include the ability to protect the brain from $\mathrm{A} \beta$ neurotoxicity and neuronal death caused by ROS [12]. Following this rationale, we designed and synthesized memantine-FA conjugates following the two routes shown in Fig. 1.

It is well known that memantine's primary amine plays a crucial role in receptor binding [13]. Thus, to preserve this moiety, we functionalized the adamantane nucleus of memantine with a carboxylic function, which acted as the reactive point for FA conjugation, affording compounds 1-3. Further, in compounds 4-7, we explored the possibility to introduce FA appendages on the nitrogen atom of memantine, whose conversion to a secondary amine has previously emerged as a feasible strategy to gain memantine-based NMDAR antagonists $[14,15]$. Synthesized compounds were first tested against NMDAR. Based on their NMDAR blocking properties, compounds were selected to study their direct and indirect antioxidant efficacy, as well as the ability to modulate the amyloidogenic pathway.

\section{Results and discussion}

\subsection{Chemistry}

Memantine-FA hybrids 1-7 were prepared following two different synthetic routes (Schemes 1 and 2), depending on the way the two pharmacophores were connected. For the synthesis of compounds 1-3, the appropriate mono Boc-protected diamine (8-10) $[16,17]$ was condensed with FA to give intermediates 11-13. Cleavage of the protecting group in acidic conditions led to compounds 14-16. Conjugation of 14-16 with 17 hydrochloride, which was obtained following a Ritter-type protocol as previously reported by Wanka et al. [18], afforded final compounds 1-3 (Scheme 1). To gain compounds 4-7, memantine hydrochloride (MEM) was alkylated with the appropriate tosyl-activated alcohol (18-21) under basic conditions to give intermediates $\mathbf{2 2 - 2 5}$ which, after carbamate depro-<smiles>COc1cc(/C=C/C(=O)O)ccc1O</smiles><smiles>COc1cc(/C=C/C(=O)NNC(=O)NC23CC4(C)CC(C)(CC(N)(C4)C2)C3)ccc1O</smiles><smiles>CC12CC3(C)CC(N)(C1)CC(C(=O)O)(C2)C3</smiles>

17

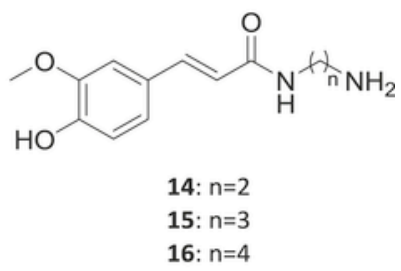

Scheme 1. Reagents and conditions: (a) EDC, $\mathrm{HOBt}, \mathrm{DMF}, \mathrm{Et}_{3} \mathrm{~N}, \mathrm{~N}_{2}, 12 \mathrm{~h}, 0^{\circ} \mathrm{C}$-rt; (b) $\mathrm{HCl} 4 \mathrm{M}$ in dioxane, $\mathrm{CH}_{2} \mathrm{Cl}_{2}, 90^{\prime}, 0^{\circ} \mathrm{C}-\mathrm{rt} ;(\mathrm{c}) \mathrm{EDC}, \mathrm{HOBt}, \mathrm{DMF}, \mathrm{N}_{2}, 36 \mathrm{~h}, 0^{\circ} \mathrm{C}-\mathrm{rt}$. 


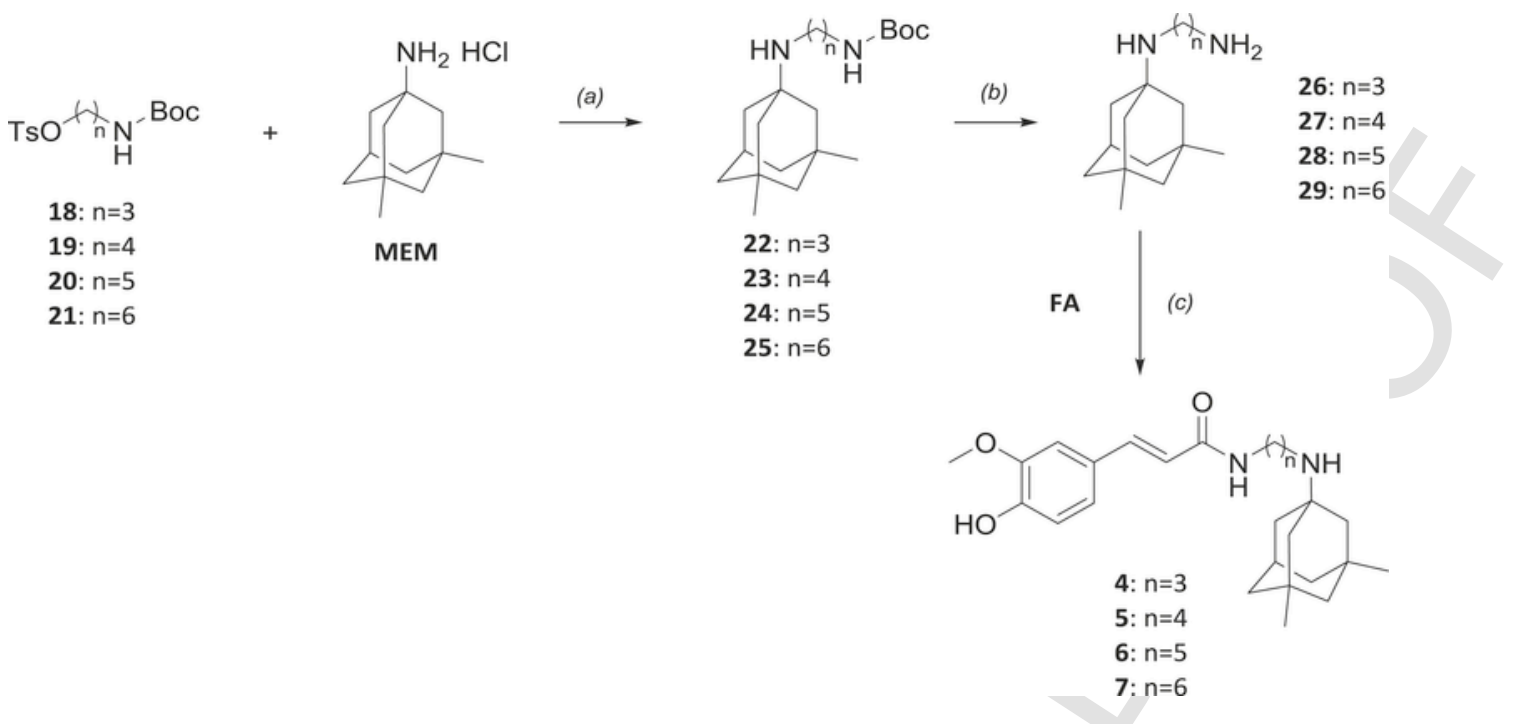

Scheme 2. Reagents and conditions: (a) $\mathrm{K}_{2} \mathrm{CO}_{3}, \mathrm{KI}, \mathrm{DMF}, 140^{\circ} \mathrm{C}, 1 \mathrm{~h}, \mathrm{MW}$; (b) $\mathrm{HCl} 4 \mathrm{M}$ in dioxane, $\mathrm{CH}_{2} \mathrm{Cl}_{2}, 20^{\prime}, 0^{\circ} \mathrm{C}-\mathrm{rt}$; (c) $\mathrm{EDC}, \mathrm{HOBt}, \mathrm{Et}_{3} \mathrm{~N}, \mathrm{DMF}, \mathrm{N}_{2}, 12 \mathrm{~h}, 0^{\circ} \mathrm{C}-\mathrm{rt}$.

tection (26-29), were coupled with FA in the presence of EDC and HOBt (Scheme 2).

\subsection{NMDAR blocking activity}

All the compounds were initially investigated to assess their effect at NMDAR. In particular, the antagonism of responses to NMDA and glycine were measured by voltage-clamp recordings on GluN1-1a/ GluN2A NMDAR expressed in Xenopus laevis oocytes at $-60 \mathrm{mV}$, with compounds 1-7 applied in tenfold increments in the range $0.01-100 \mu \mathrm{M}$. Memantine was used as the reference compound. Compounds 1-3, which retain the primary amine function of memantine, demonstrated very low or no potency to block NMDAR (Fig. 2A). Conversely, employing memantine's amine for connecting FA appendages resulted in significant blocking of NMDA/glycine responses (Fig. 2A).

Compounds 5-7 presented a micromolar profile, with $\mathrm{IC}_{50}$ values ranging from 6.9 to $23.9 \mu \mathrm{M}$, while the shorter compound $\mathbf{4}$ had an $\mathrm{IC}_{50}$ greater than $100 \mu \mathrm{M}$, thus suggesting its inefficacy (Table 1). Blocking properties toward NMDAR were influenced by the chain length separating the pharmacophoric functions, with compound 7, carrying a hexamethylene spacer, emerging as the most efficacious. Compounds with considerable blocking properties (5-7) were assessed for voltage dependency. The compounds were diluted to their approximate $\mathrm{IC}_{50}$ concentrations and block of NMDA/glycine responses mediated by GluN1-1a/GluN2A was measured at four different holding potentials $(-40,-60,-80$ and $-100 \mathrm{mV})$.

Compounds presented a voltage-dependent behavior, acting, like memantine, as open channel blockers of the receptor. Data were fitted with the Woodhull equation to determine their $\delta$ values, and thus estimate the position of the binding site within the membrane electric field $[19,20]$. The results of this study showed that three of the new molecules yielded $\delta$ values comparable to memantine. Compounds 5, $\mathbf{6}$ and 7 had $\delta$ values in the range $0.43-0.51$, which are just slightly higher to that of memantine, 0.39 . Based on their $\delta$ values, we can suggest these compounds may have a binding site midway through the pore, maybe a little deeper but overlapping with that of memantine. This is consistent with binding adjacent to the $\mathrm{Q} / \mathrm{R} / \mathrm{N}$-site that determines ion selectivity in ionotropic glutamate receptors.
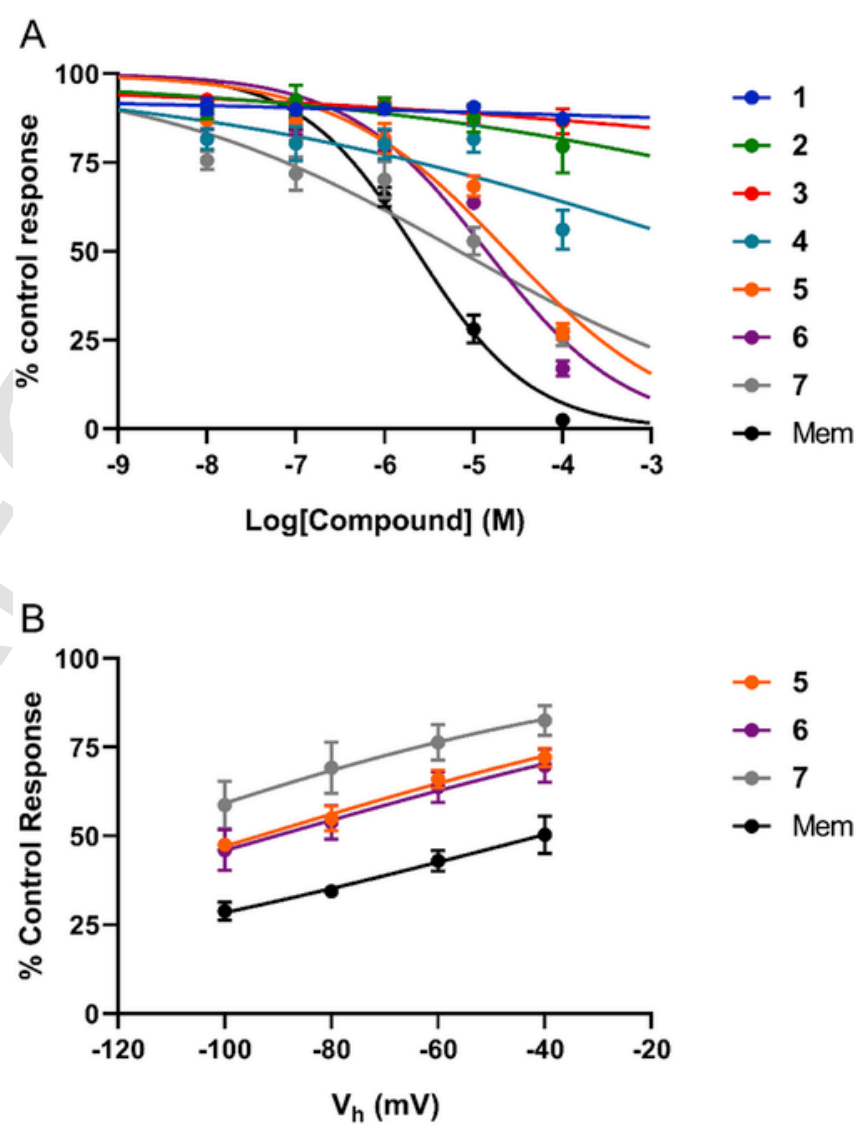

Fig. 2. A) Concentration-inhibition curves for compounds 1-7 in comparison to memantine (Mem). Data are mean \% of control response to $100 \mu \mathrm{M}$ NMDA $(+10 \mu \mathrm{M}$ glycine) \pm SEM ( $\mathrm{n}=5-7$ separate oocytes). The curves are fits to Equation (1) and $\mathrm{IC}_{50}$ values are given in Table 1. B) Voltage dependence of inhibition by compounds 5-7 $(30 \mu \mathrm{M}, 20 \mu \mathrm{M}$ and $10 \mu \mathrm{M}$ respectively) in comparison to memantine (Mem; $3 \mu \mathrm{M})$. Data are plotted as mean $\%$ control response to $100 \mu \mathrm{M}$ NMDA $(+10 \mu \mathrm{M}$ glycine $) \pm$ SEM against the holding potential $\left(\mathrm{V}_{\mathrm{h}}\right)(\mathrm{n}=5-6$ separate oocytes $)$. The curves are fits of Equation (2) and $\delta$ values are given in Table 1. 
Table 1

$\mathrm{IC}_{50}$ and $\delta$ values for compounds $\mathbf{1 - 7}$ and memantine.

\begin{tabular}{lll}
\hline Compound & $\mathrm{IC}_{50}[95 \% \mathrm{CI}] \mu \mathrm{M}(\mathrm{n})$ & $\delta \pm \mathrm{SE}(\mathrm{n})$ \\
\hline 1 & $\gg 100(7)$ & $\mathrm{nd}$ \\
2 & $\gg 100(6)$ & $\mathrm{nd}$ \\
3 & $\gg 100(6)$ & nd \\
4 & $>100(5)$ & nd \\
5 & $23.9[13.0-49.4](5)$ & $0.46 \pm 0.07(6)$ \\
6 & $14.1[8.7-22.6](5)$ & $0.43 \pm 0.12(6)$ \\
7 & $6.9[3.0-19.2](5)$ & $0.51 \pm 0.17(6)$ \\
memantine & $2.3[1.7-3.0](6)$ & $0.39 \pm 0.08(5)$ \\
\hline
\end{tabular}

$\mathrm{nd}=$ not determined (because inhibition was too weak).

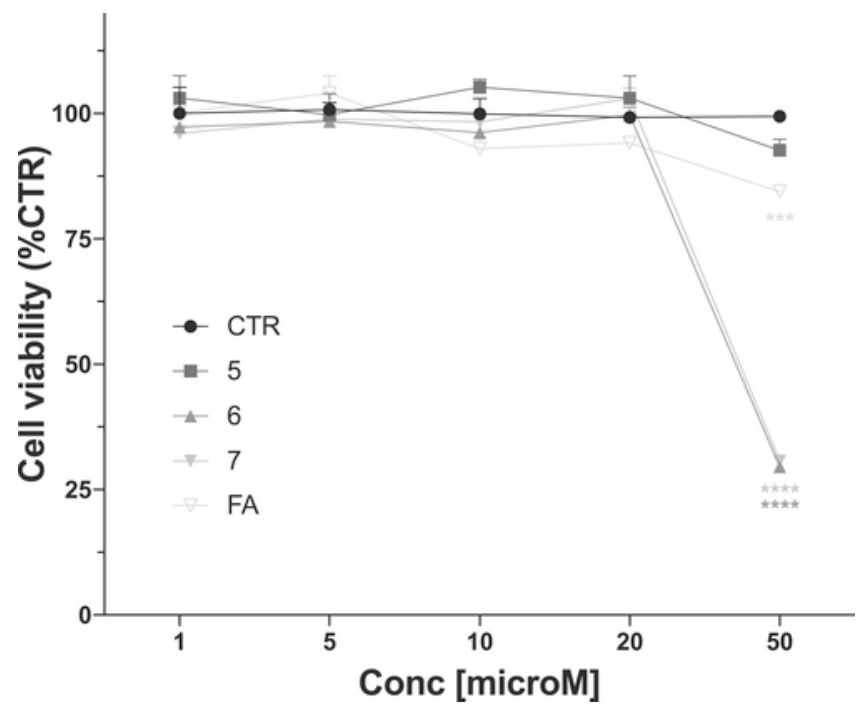

Fig. 3. Cellular toxicity of hybrid compounds (5-7) and Ferulic Acid (FA) on human neuroblastoma SH-SY5Y. Cells were treated with compounds for $24 \mathrm{~h}$ at different concentrations ranging from 1 to $50 \mu \mathrm{M}$. Cell viability was assessed by MTT assay. Data are expressed as percentage of cell viability versus CTR; ${ }^{* *} p<0.001$, and $* * * * p<0.0001$ versus CTR; Dunnett's multiple comparison test, $\mathrm{n}=3$.

\subsection{Cell toxicity assay}

Compounds 5-7, presenting appreciable NMDAR blocking properties, were selected for deepening their antioxidant profile in SH-SY5Y human neuroblastoma cells. To this aim, we assessed the cytotoxicity of compounds 5-7 to define the concentration range to be used in cellular experimental settings. The antioxidant FA was used for comparison. Cells were exposed to the compounds at concentrations ranging from 1 to $50 \mu \mathrm{M}$ for $24 \mathrm{~h}$ and cell viability was determined by MTT assay. As shown in Fig. 3, all the compounds were devoid of any toxicity at a concentration up to $20 \mu \mathrm{M}$, while only the shorter derivative $\mathbf{5}$ retained, like FA, good tolerability up to $50 \mu \mathrm{M}$. Lack of toxicity was verified also for compound 4 , carrying a three methylene spacer, at all the concentrations investigated (data not shown), confirming that the spacer length significantly influenced compound tolerability in favor of shorter derivatives.

\subsection{Protective effect toward $\mathrm{H}_{2} \mathrm{O}_{2}$-Induced damage}

To determine the antioxidant efficacy of compounds 5-7, we first studied their ROS scavenging activity when coincubated with $300 \mathrm{MMH}_{2} \mathrm{O}_{2}$, using FA for comparison. The scavenger effect was evaluated in SH-SY5Y cells by using the fluorescent probe dichlorodihydrofluorescein diacetate (DCFH-DA) as a marker for quantitative intracellular ROS formation. The DCFH-fluorescence intensity significantly increased in $\mathrm{H}_{2} \mathrm{O}_{2}$-treated cells (black line, Fig. 4A) with respect to untreated cells (dashed grey line, Fig. 4A). All compounds, at a concentration of $10 \mu \mathrm{M}$, were able to markedly reduce $\mathrm{H}_{2} \mathrm{O}_{2}$-induced intracellular ROS formation, being, however, less effective than FA. To assess if indirect antioxidant effects could accompany radical scavenger properties, further experiments were performed pretreating SH-SY5Y cells with compounds 5-7 $(10 \mu \mathrm{M})$ for $24 \mathrm{~h}$ before adding $300 \mathrm{\mu MH}_{2} \mathrm{O}_{2}$ (Fig. 4B). Again, compounds 5-7 produced a significant reduction in DCHF-fluorescent intensity, albeit an inversion in the trend of efficacy was observed. Indeed, with this experimental setting, compound 7 emerged as the most efficacious, reaching FA ability to counteract $\mathrm{H}_{2} \mathrm{O}_{2}$-induced ROS formation. Based on these results, we could speculate that, at least for 7,
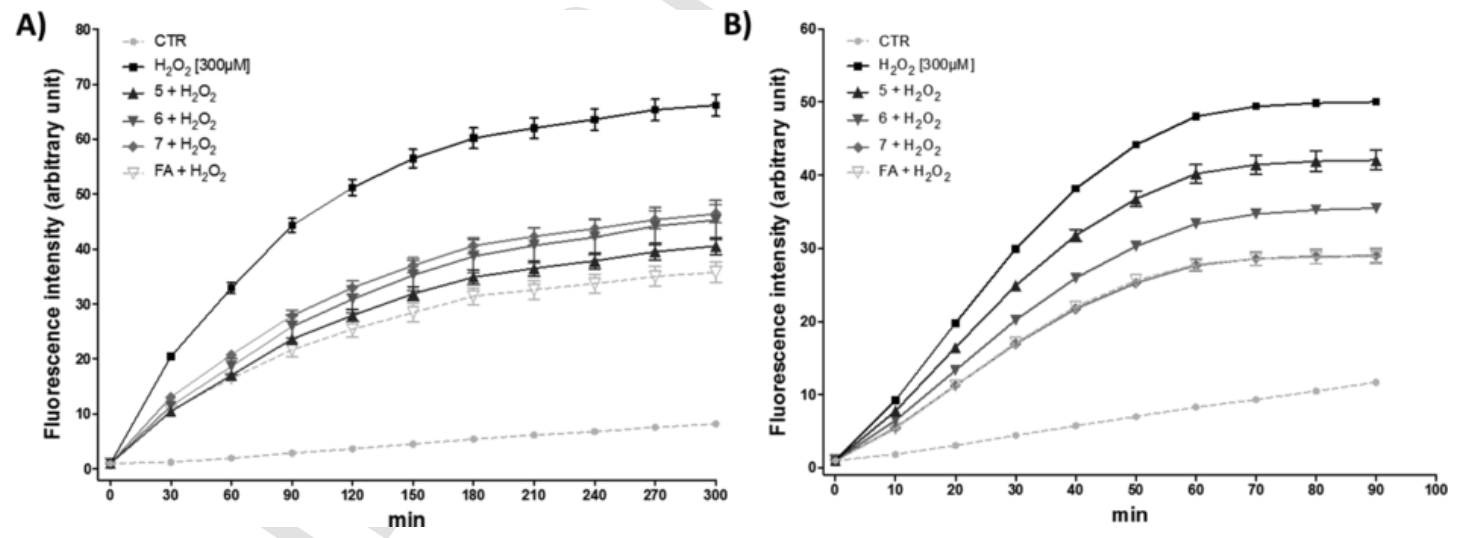

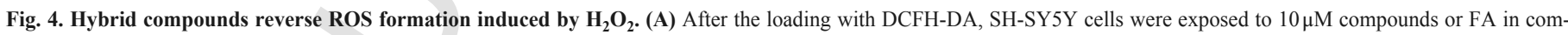

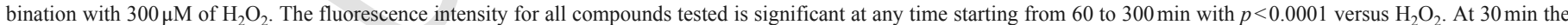

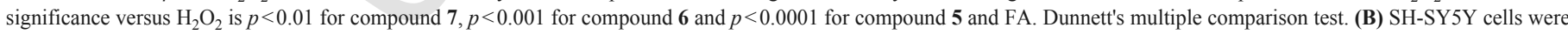

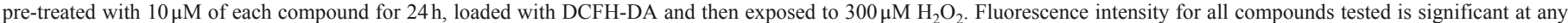

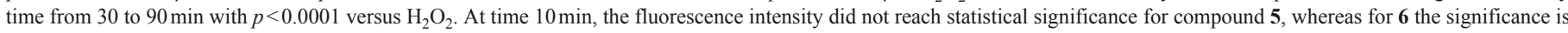

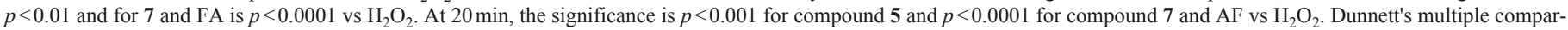
ison test. 
antioxidant properties might derive from both direct and indirect effects.

\subsection{Activation of Nrf2 pathway in SH-SY5Y cells}

The nuclear factor (erythroid-derived 2)-like 2 (Nrf2) transcriptional pathway is a major player of inducible antioxidant defense [21]. Activation of the Nrf2 pathway, and the subsequent transcription of downstream cytoprotective genes, is triggered by the disruption of interaction and binding of Nrf2 with the cytosolic Nrf2 repressor Kelch-like ECH-associated protein 1 (Keap 1) [22]. A variety of electrophiles from synthetic or natural sources is emerging for their ability to hamper this interaction by targeting key cysteine residues of Keap1, which act as sensors of oxidative insults [23]. In particular, the electrophilic motif recurring in FA and its derivatives, namely the $\alpha, \beta$-unsaturated carbonyl group, has already been shown to trigger the Nrf2-driven transcriptional process in a series of hydroxy-cinnamic derivatives for which trapping Keap1 through covalent adduct formation was proposed to be the initiating event $[24,25]$. Thus, we studied compounds 5-7 and FA in SH-SY5Y neuroblastoma cells to verify whether they may affect the Nrf2 pathway and indirect mechanisms could therefore contribute to their overall antioxidant profile. To this aim, we first assessed their ability to modulate the mRNA levels of Nrf2 by real-time PCR, using $10 \mu \mathrm{M}$ of each compound incubated for $6 \mathrm{~h}$. Notably, only compound 7 determined a significant increase in Nrf2 mRNA expression (Fig. 5, panel A), while cells treated with FA or compounds 5 and $\mathbf{6}$ behaved like untreated cells. Coherently with these results, the same trend was observed when we investigated the ability of compounds to tune the mRNA levels of heme oxygenase-1 (HO-1), a prototypical Nrf2-target gene related to oxidative stress response. Indeed, mRNA levels of the inducible cytoprotective gene raised to about $150 \%$ of control following pretreatment with $10 \mu \mathrm{M} 7$, while no effect was elicited by FA or compounds 5 and 6 (Fig. 5, panel B).

Then, we sought to verify whether the increase in HO-1 mRNA expression determined by compound 7 could effectively result in enhanced HO-1 protein levels. To this aim, HO-1 induction was analyzed by means of Western immunoblotting in the same cell line after treatment for $24 \mathrm{~h}$ with 7 at 10 or $20 \mu \mathrm{M}$. Interestingly, compound 7 caused a dose-dependent increase of HO-1 expression, with cells treated with $20 \mu \mathrm{M} 7$ almost doubling HO-1 protein levels of control (Fig. 6). These results confirm that compound 7 is a multimodal antioxidant, which combines radical scavenging properties to the ability of potentiating the Nrf2/HO-1 axis. Further, the lack of indirect antioxidant efficacy verified for compounds 5, 6 and FA, all
A)

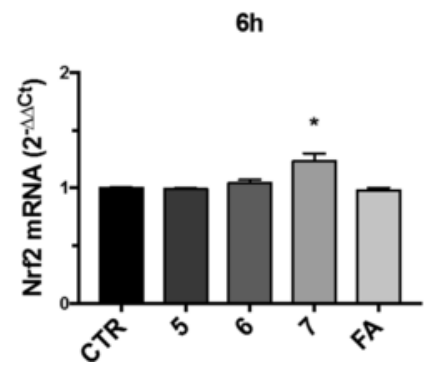

B)

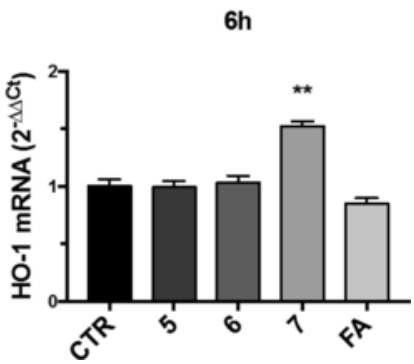

Fig. 5. Hybrid compounds modulate Nrf2 and HO-1 mRNA levels. RNA was obtained from cellular extracts of SH-SY5Y cells treated for $6 \mathrm{~h}$ with compounds 5-7 and FA at $10 \mu \mathrm{M}$ and analyzed for Nrf2 (A) and HO-1 (B) mRNA expression by RT-PCR. GAPDH was used as housekeeping gene. Results are shown as mean $\pm \mathrm{SEM} ;{ }^{*} p<0.05$, ${ }^{* *} p<0.01$ versus CTR; Dunnett's multiple comparison test, $\mathrm{n}=3$.

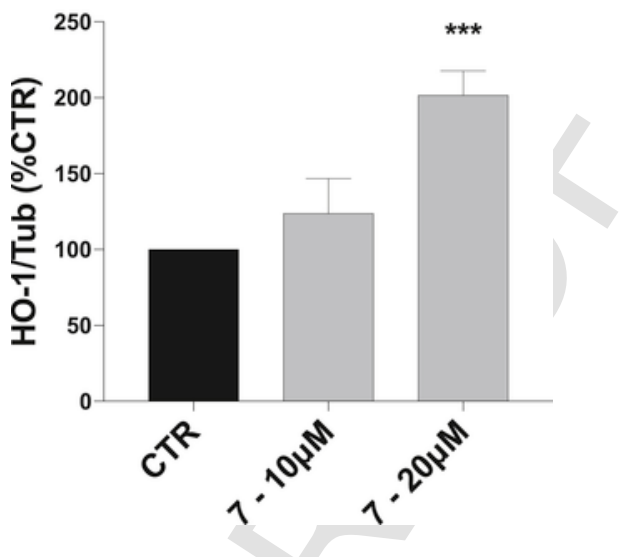

Fig. 6. Effect of compound 7 on HO-1 protein levels. Cellular extracts of SH-SY5Y cells treated for $24 \mathrm{~h}$ with compound 7 at 10 or $20 \mu \mathrm{M}$ were analyzed for HO-1 protein levels by Western Blot. Anti-tubulin was used as protein loading control. Results are shown as ratio (\% of CTR) $\pm \mathrm{SEM} ; * * * p<0.001$ versus CTR; Dunnett's multiple comparison test, $\mathrm{n}=3$.

carrying the $\alpha, \beta$-unsaturated carbonyl feature, reveal that an electrophilic moiety is not per se sufficient for activating redox sensor proteins, and shape complementarity may play a pivotal role in this respect. Particularly, we might speculate that compounds 5-7, varying in the linker length, and FA could differently orient their cysteine-reactive group toward nucleophilic traps of Keap1 affecting target recognition and, consequently, a compound's reactivity and specificity.

\subsection{APP processing in $H 4-S W$ cells}

In $\mathrm{AD}$, a direct link exists between eNMDAR overactivation and increased neuronal A $\beta$ production [26]. NMDAR have been proposed to modulate $\alpha$-secretase activity, shifting APP metabolism towards a non-amyloidogenic pathway. Memantine has been shown to lower A $\beta$ synthesis in a number of studies $[27,28]$. Mechanisms potentially involved in memantine-driven $A \beta$ modulation are not completely clear, and both NMDAR-mediated and NMDAR-independent mechanisms have been proposed [29]. In this context, we sought to investigate whether the most promising compounds 5-7 could affect the APP processing favoring the production of the non-amyloidogenic soluble amyloid precursor protein $\alpha(\operatorname{sAPP} \alpha)$. Current research suggests that SAPP $\alpha$ plays a role in synaptic growth and plasticity, featuring neuroprotective and neurotrophic properties [30]. Thus, we studied the effect of the compounds on SAPP $\alpha$ levels in the human H4 cell line expressing the Swedish mutant form of APP (H4-SW), after $24 \mathrm{~h}$ treatment. Compounds 5-7 were tested at $10 \mu \mathrm{M}$ concentration, which had no impact on cell viability, as confirmed by a dose-response curve where memantine, FA and compounds 5-7 had no toxic effect up to $20 \mu \mathrm{M}$ concentration (data not shown). Memantine and FA alone were used for comparison. The Western blot analysis reported in Fig. 7 shows that compound 7, but not compounds $\mathbf{5}$ and $\mathbf{6}$, significantly increased sAPP $\alpha$ levels (Fig. 7, panel A).

Notably, compounds 5-7 were not able to affect full-length APP (fl-APP) expression levels, which was determined in the same cells to evaluate the effect of the compounds on total intracellular APP (Fig. 7, panel B). By enhancing sAPP $\alpha$ levels without affecting the levels of total intracellular APP, compound 7 seems to stimulate APP processing towards the $\alpha$-secretase (non-amyloidogenic) pathway, which should result in decreased $A \beta$ production. Noteworthy, at the same 

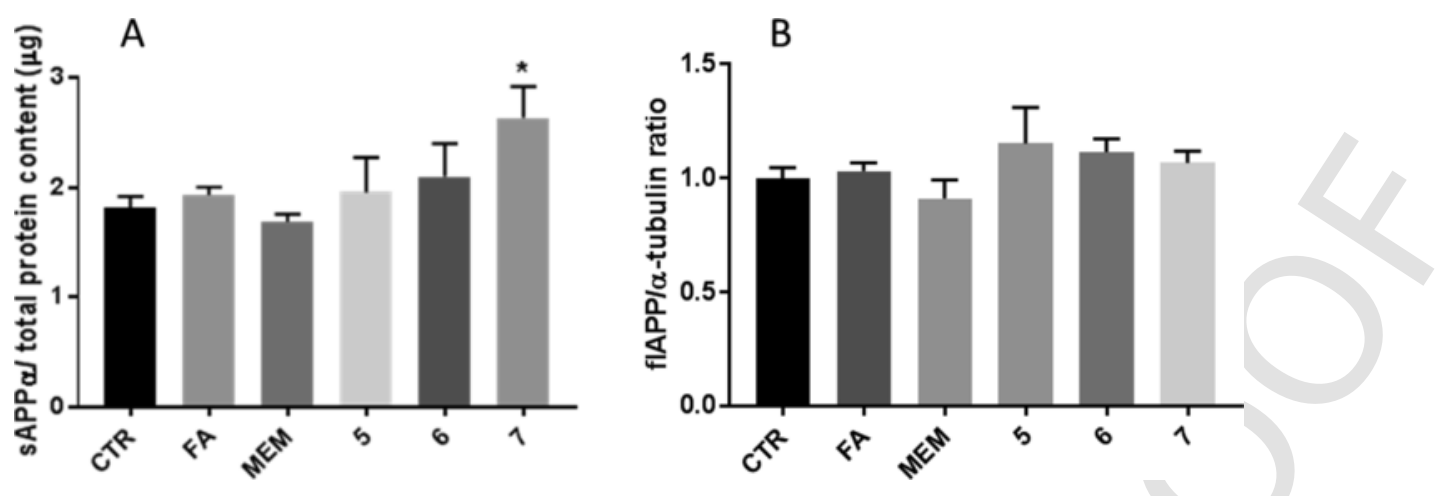

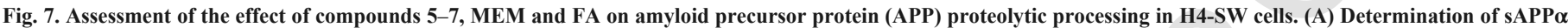

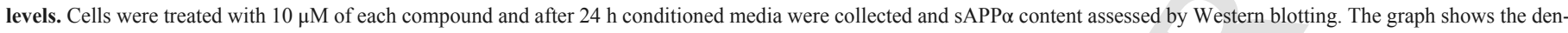

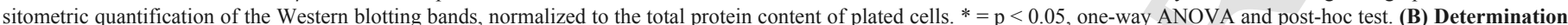

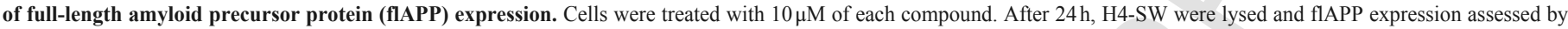
Western blotting. The graph shows the densitometric quantification of the Western blotting bands, normalized to $\alpha$-tubulin as internal reference.

concentration, memantine and FA alone showed no effect on APP processing, strengthening the value of the design of a hybrid molecule. The lack of efficacy of memantine, whose potency as NMDAR antagonist is 3-fold higher than that of 7, suggests that the effect of 7 on APP processing we observed in this experimental setting seems to be not principally mediated by NMDAR. Interestingly, lengthening of the linker between the pharmacophoric functions up to six methylenes switched on the efficacy toward both APP processing and Nrf2 activation, pointing to 7 as the most promising molecule of the series.

\section{Conclusions}

NMDAR play a crucial role in the pathophysiology of AD. Excessive activation of NMDAR can compromise synapse function by triggering neurotoxic events, which involve $\mathrm{A} \beta$ peptide and oxidative stress. By preferentially blocking extrasynaptic rather than synaptic currents, the anti-AD drug memantine limits neurotoxicity mediated by excessive NMDAR activity while relatively sparing physiological neurotransmission. This peculiar NMDAR profile prompted us to conjugate memantine with the bioactive payload FA, aiming to synergistically modulate the critical partnership occurring between oxidative damage, $\mathrm{A} \beta$ burden, and hyperfunctioning NMDAR. For compounds 4-7, which exploit memantine's nitrogen for FA connection, chain lengthening positively influenced NMDAR blocking properties. The longer derivative 7 , carrying a hexamethylene spacer between the pharmacophoric functions, presented a micromolar profile as NMDAR antagonist $\left(\mathrm{IC}_{50}=6.9 \mu \mathrm{M}\right)$, being only three times less effective than the parent compound memantine $\left(\mathrm{IC}_{50}=2.3 \mu \mathrm{M}\right)$. Further, compound 7 also shares with memantine the binding site midway through the pore and a voltage-dependent behavior, suggesting that conjugation with FA produced only a modest perturbation of memantine's NMDAR binding mode. Compounds with appreciable NMDAR blocking properties were studied in SH-SY5Y cells to assess their antioxidant properties. All compounds tested showed notable free radical scavenging effects. Conversely, only 7 was able to significantly potentiate the expression of $\mathrm{Nrf} 2$ and its downstream protective gene HO-1 at the concentration of $10 \mu \mathrm{M}$, therefore emerging as a multimodal antioxidant. Notably, the lack of indirect antioxidant efficacy observed for $\mathbf{5}$ and $\mathbf{6}$, varying in the linker length, and FA, suggests the importance of target recognition as a pre-requisite for electrophile reactivity, excluding an indiscriminate effect driven by the $\alpha, \beta$-unsaturated carbonyl group. At the same concentration $(10 \mu \mathrm{M})$, compound 7 , and not shorter derivatives
5 and 6, significantly enhanced sAPP $\alpha$ levels in H4-SW cells, suggesting that it may stimulate APP processing in favor of the $\alpha$-secretase (non-amyloidogenic) pathway and consequently limit $\mathrm{A} \beta$ formation. Thus, the most potent NMDAR antagonist 7 was also able to activate inducible protective pathways which play a crucial role in contrasting the neurotoxic cascade driven by eNMDAR overactivation. The multimodal profile of compound 7 was well balanced, in the micromolar-range, and not accompanied by any cytotoxicity in both SH-SY5Y and H4-SW cells up to the concentration of $20 \mu \mathrm{M}$. Based on these findings, compound 7 emerges as a promising pharmacologic tool for deepening our insight on the significance of NMDAR-mediated neurotoxic events involving ROS formation and $\mathrm{A} \beta$ damage.

\section{Experimental section}

\subsection{Chemistry}

Chemical reagents were purchased from Sigma-Aldrich, Fluka and Lancaster (Italy) and used without further purification. Chromatographic separations were performed on silica gel columns (Kieselgel 40, 0.040-0.063 mm, Merck) by chromatography. Reactions were followed by TLC on Merck $(0.25 \mathrm{~mm})$ glass-packed precoated silica gel plates (60 F254), then visualized with an UV lamp, bromocresol green or $\mathrm{KMnO}_{4}$. Melting points were measured in glass capillary tubes on a Büchi SMP-20 apparatus and are uncorrected. Microwave assisted synthesis was performed by using CEM Discover ${ }^{\circledR} \mathrm{SP}$ apparatus $(2.45 \mathrm{GHz}$, maximum power of $300 \mathrm{~W})$. NMR spectra were recorded at $400 \mathrm{MHz}$ for ${ }^{1} \mathrm{H}$ and $100 \mathrm{MHz}$ for ${ }^{13} \mathrm{C}$ on Varian VXR 400 spectrometer. Chemical shifts $(\delta)$ are reported in parts per millions (ppm) relative to tetramethylsilane (TMS), and spin multiplicities are given as s (singlet), br s (broad singlet), d (doublet), t (triplet), $\mathrm{q}$ (quartet), or $\mathrm{m}$ (multiplet). Direct infusion ESI-MS mass spectra were recorded on a Waters ZQ 4000 apparatus. Final compounds 1-7 were $>95 \%$ pure as determined by HPLC analyses. The analyses were performed under reversed-phase conditions on a Phenomenex Jupiter C18 $(150 \times 4.6 \mathrm{~mm}$ I.D. $)$ column, using a binary mixture of $0.1 \%$ TFA in $\mathrm{H}_{2} \mathrm{O}$ /acetonitrile $(70 / 30, \mathrm{v} / \mathrm{v}$ for $\mathbf{5} ; 65 / 35$, v/v for $\mathbf{3}, \mathbf{4}, \mathbf{6}, \mathbf{7} ; 80 / 20$, $\mathrm{v} / \mathrm{v}$ for $\mathbf{1}, \mathbf{2}$ ) as the mobile phase, UV detection at $\lambda=302 \mathrm{~nm}$ and a flow rate of $1 \mathrm{~mL} / \mathrm{min}$. Analyses were performed on a liquid chromatograph model PU-2089Plus UV equipped with a $20 \mu \mathrm{L}$ loop valve (Jasco Europe, Italy). Compounds were named relying on the naming algorithm developed by CambridgeSoft Corporation and used in Chem-BioDrawUltra 15.1. 


\subsubsection{General procedure for the intermediates 11-13}

To an ice-cooled solution of ferulic acid (FA, 1 equiv) in dry DMF (3-4 mL) were added HOBt (1.3 equiv) and EDC (1.3 equiv). The reaction mixture was stirred for $10 \mathrm{~min}$, followed by addition of $\mathrm{Et}_{3} \mathrm{~N}$ (1.3 equiv) and the appropriate mono-protected diamine $(\mathbf{8}-\mathbf{1 0})$ (1 equiv). Stirring was then continued at room temperature overnight, and the solvent evaporated under vacuum. The crude was purified by flash chromatography on silica gel using dichloromethane/methanol $(9.5: 0.5)$ as mobile phase.

\subsection{2. tert-butyl (E)-(2-(3-(4-hydroxy-3-}

methoxyphenyl)acrylamido)ethyl) carbamate (11)

Synthesized from FA (400 mg, $2.06 \mathrm{mmol})$ and 8 [17](330 mg, $2.06 \mathrm{mmol})$ to afford $\mathbf{1 1}$ as waxy solid: $200 \mathrm{mg}(30 \%) ;{ }^{1} \mathrm{H}$ NMR $\left(400 \mathrm{MHz}, \mathrm{CDCl}_{3}\right) \delta 7.50(\mathrm{~d}, J=15.6 \mathrm{~Hz}, 1 \mathrm{H}), 6.99(\mathrm{~d}, J=8 \mathrm{~Hz}, 1 \mathrm{H})$, $6.94(\mathrm{~s}, 1 \mathrm{H}), 6.88(\mathrm{~d}, J=8.4 \mathrm{~Hz}, 1 \mathrm{H}), 6.60($ br s, $1 \mathrm{H}), 6.26(\mathrm{~d}$, $J=15.6 \mathrm{~Hz}, 1 \mathrm{H}), 5.33$ (br s, 1H), $3.85(\mathrm{~s}, 3 \mathrm{H}), 3.50-3.46(\mathrm{~m}, 2 \mathrm{H})$, $3.33-3.30(\mathrm{~m}, 2 \mathrm{H}), 1.42(\mathrm{~s}, 9 \mathrm{H})$.

\subsection{3. tert-butyl (E)-(3-(3-(4-hydroxy-3-}

\section{methoxyphenyl)acrylamido)propyl)carbamate (12)}

Synthesized from FA (100 mg, $0.51 \mathrm{mmol})$ and 9 [16](174 mg, $0.51 \mathrm{mmol})$ to afford 12 as waxy solid: $100 \mathrm{mg}(56 \%) ;{ }^{1} \mathrm{H}$ NMR $\left(400 \mathrm{MHz}, \mathrm{CDCl}_{3}\right) \delta 7.55(\mathrm{~d}, J=15.2 \mathrm{~Hz}, 1 \mathrm{H}), 7.05(\mathrm{~d}, J=8 \mathrm{~Hz}, 1 \mathrm{H})$, $7.01(\mathrm{~s}, 1 \mathrm{H}), 6.90(\mathrm{~d}, J=8 \mathrm{~Hz}, 1 \mathrm{H}), 6.50(\mathrm{br} \mathrm{s}, 1 \mathrm{H}), 6.30(\mathrm{~d}, J=15.2 \mathrm{~Hz}$, $1 \mathrm{H}), 4.96($ br s, $1 \mathrm{H}), 3.92(\mathrm{~s}, 3 \mathrm{H}), 3.44-3.40(\mathrm{~m}, 2 \mathrm{H}), 3.23-3.19(\mathrm{~m}$, 2H), 1.67-1.61 (m, 2H), 1.45 (s, 9H).

\subsection{4. tert-butyl (E)-(4-(3-(4-hydroxy-3-}

\section{methoxyphenyl)acrylamido)butyl)carbamate (13)}

Synthesized from FA (400 mg, $2.06 \mathrm{mmol})$ and 10 [31](188 mg, $2.06 \mathrm{mmol})$ to afford 13 as waxy green solid: $230 \mathrm{mg}(33 \%) ;{ }^{1} \mathrm{H}$ NMR $\left(400 \mathrm{MHz}, \mathrm{CDCl}_{3}\right) \delta 7.52(\mathrm{~d}, J=15.2 \mathrm{~Hz}, 1 \mathrm{H}), 7.03(\mathrm{~d}, J=8.4 \mathrm{~Hz}, 1 \mathrm{H})$, $6.98(\mathrm{~s}, 1 \mathrm{H}), 6.88(\mathrm{~d}, J=8 \mathrm{~Hz}, 1 \mathrm{H}), 6.25$ (d, $J=15.2 \mathrm{~Hz}, 1 \mathrm{H}), 6.01(\mathrm{br}$ s, 1H), 4.64 (br s, 1H), 3.89 (s, 3H), 3.39-3.38 (m, 2H), 3.17-3.13 (m, 2H), 1.60-1.55 (m, 4H), 1.43 (s, 9H).

\subsubsection{General procedure for the intermediates 14-16}

To an ice-cooled solution of the appropriate Boc-protected intermediate (11-13, 1 equiv) in $\mathrm{CH}_{2} \mathrm{Cl}_{2}(2-3 \mathrm{~mL})$ was added $\mathrm{HCl} 4 \mathrm{M}$ in dioxane $(2-3 \mathrm{~mL})$ and the reaction mixture was stirred at $0{ }^{\circ} \mathrm{C}$ for $90 \mathrm{~min}$. The solvent was evaporated and the crude purified by flash chromatography on silica gel using dichloromethane/methanol/aqueous ammonia $33 \%(8: 2: 0.2)$ affording desired intermediates as free bases.

4.1.6. (E)-N-(2-aminoethyl)-3-(4-hydroxy-3methoxyphenyl)acrylamide (14)

Synthesized from $11(200 \mathrm{mg}, 0.60 \mathrm{mmol})$ to afford 14 as pale yellow solid: $120 \mathrm{mg}(86 \%) ;{ }^{1} \mathrm{H}$ NMR $\left(400 \mathrm{MHz}, \mathrm{DMSO}-d_{6}\right) \delta 8.34(\mathrm{t}$, $J=5.4 \mathrm{~Hz}, 1 \mathrm{H}), 7.72(\mathrm{~d}, J=15.6 \mathrm{~Hz}, 1 \mathrm{H}), 7.53(\mathrm{~s}, 1 \mathrm{H}), 7.41-7.38(\mathrm{~m}$, $1 \mathrm{H}), 7.20(\mathrm{~d}, J=7.6 \mathrm{~Hz}, 1 \mathrm{H}), 6.86(\mathrm{~d}, J=15.6 \mathrm{~Hz}, 1 \mathrm{H}), 4.21(\mathrm{~s}, 3 \mathrm{H})$, 3.59-3.55 (m, 2H), 3.04-3.00 (m, 2H), 2.92 (br s, 2H).

\subsection{7. (E)-N-(3-aminopropyl)-3-(4-hydroxy-3-}

methoxyphenyl)acrylamide (15)

Synthesized from $12(100 \mathrm{mg}, 0.30 \mathrm{mmol})$ to afford $\mathbf{1 5}$ as pale green solid: $71 \mathrm{mg}(99 \%) ;{ }^{1} \mathrm{H}$ NMR $\left(400 \mathrm{MHz}, \mathrm{CD}_{3} \mathrm{OD}\right) \delta 7.40(\mathrm{~d}$, $J=15.6 \mathrm{~Hz}, 1 \mathrm{H}), 7.10(\mathrm{~s}, 1 \mathrm{H}), 7.00-6.98(\mathrm{~m}, 1 \mathrm{H}), 6.77$ (d, $J=8.4 \mathrm{~Hz}$, $1 \mathrm{H}), 6.48(\mathrm{~d}, J=15.6 \mathrm{~Hz}, 1 \mathrm{H}), 3.84(\mathrm{~s}, 3 \mathrm{H}), 3.38(\mathrm{t}, J=6.4 \mathrm{~Hz}, 2 \mathrm{H})$, $2.96(\mathrm{t}, J=7.2 \mathrm{~Hz}, 2 \mathrm{H}), 1.95-1.88(\mathrm{~m}, 2 \mathrm{H})$.
4.1.8. (E)-N-(4-aminobutyl)-3-(4-hydroxy-3-

methoxyphenyl)acrylamide (16)

Synthesized from $13(230 \mathrm{mg}, 0.63 \mathrm{mmol})$ to afford $\mathbf{1 6}$ as pale green solid: $160 \mathrm{mg}(96 \%) ;{ }^{1} \mathrm{H}$ NMR $\left(400 \mathrm{MHz}, \mathrm{CD}_{3} \mathrm{OD}\right) \delta 7.39$ (d, $J=15.6 \mathrm{~Hz}, 1 \mathrm{H}), 7.05(\mathrm{~s}, 1 \mathrm{H}), 6.96(\mathrm{~d}, J=7.6 \mathrm{~Hz}, 1 \mathrm{H}), 6.73(\mathrm{~d}$, $J=8.4 \mathrm{~Hz}, 1 \mathrm{H}), 6.40(\mathrm{~d}, J=15.6 \mathrm{~Hz}, 1 \mathrm{H}), 3.82(\mathrm{~s}, 3 \mathrm{H}), 3.31-3.23(\mathrm{~m}$, $2 \mathrm{H}), 2.80-2.78(\mathrm{~m}, 2 \mathrm{H}), 1.59-1.58(\mathrm{~m}, 4 \mathrm{H})$.

\subsubsection{General procedure for compounds $1-3$}

To an ice-cooled solution of the hydrochloride salt 17 [18](1 equiv) in dry DMF ( $3 \mathrm{~mL})$ were added HOBt (1.3 equiv) and $\mathrm{EDC}$ (1.3 equiv) under $\mathrm{N}_{2}$ atmosphere. The reaction mixture was stirred for $10 \mathrm{~min}$, followed by addition of the appropriate intermediates (14-16) (2 equiv). Stirring was continued at room temperature for $36-48 \mathrm{~h}$, and then the solvent evaporated under vacuum. The crude was purified by column chromatography on silica gel using dichloromethane/methanol/aqueous ammonia $33 \%(8.5: 1.5: 0.15)$ as mobile phase.

\subsubsection{0. (1r,3s, 5R, 7S)-3-amino- $N-(2-((E)-3-(4-h y d r o x y-3-$} methoxyphenyl)acrylamido)ethyl)-5,7-dimethyladamantane-1carboxamide (1)

Synthesized from 17 (64 mg, $0.24 \mathrm{mmol})$ and $14(115 \mathrm{mg}$, $0.48 \mathrm{mmol})$ to afford 1 as green solid: $80 \mathrm{mg}(74 \%)$; $\mathrm{mp} 122-124^{\circ} \mathrm{C}$; ${ }^{1} \mathrm{H}$ NMR (400 MHz, DMSO- $d_{6}$ ) $\delta 7.99$ (br s, 1H), 7.46 (br s, $1 \mathrm{H}$ ), $7.32(\mathrm{~d}, J=15.6 \mathrm{~Hz}, 1 \mathrm{H}), 7.11(\mathrm{~s}, 1 \mathrm{H}), 6.99-6.97(\mathrm{~m}, 1 \mathrm{H}), 6.80(\mathrm{~d}$, $J=8.4 \mathrm{~Hz}, 1 \mathrm{H}), 6.40(\mathrm{~d}, J=15.6 \mathrm{~Hz}, 1 \mathrm{H}), 3.80(\mathrm{~s}, 3 \mathrm{H}), 3.20-3.17(\mathrm{~m}$, 2H), 3.15-3.12 (m, 2H), 1.40 (s, 2H), 1.29-1.23 (m, 4H), 1.16-1.12 $(\mathrm{m}, 4 \mathrm{H}), 1.01(\mathrm{~s}, 2 \mathrm{H}), 0.82(\mathrm{~s}, 6 \mathrm{H}) .{ }^{13} \mathrm{C}$ NMR (100 MHz, DMSO- $\left.d_{6}\right)$ $\delta 176.77,166.17,148.84,148.27,139.54,126.70,121.97,119.25$, 116.10, 111.23, 55.96, 51.30, 49.90, 49.79, 49.03, 46.18, 44.55, 44.10, 38.90, 32.95, 30.19. MS [ESI+] $m / z 442[\mathrm{M}+1]^{+}$.

4.1.11. (1r,3s, 5R, 7S)-3-amino- $N-(3-((E)-3-(4-h y d r o x y-3-$ methoxyphenyl)acrylamido)propyl)-5,7-dimethyladamantane-1carboxamide (2)

Synthesized from $17(37 \mathrm{mg}, 0.14 \mathrm{mmol})$ and $15(71 \mathrm{mg}$, $0.28 \mathrm{mmol})$ to afford 2 as green solid: $31 \mathrm{mg}(52 \%) ; \mathrm{mp} 118-119^{\circ} \mathrm{C}$; ${ }^{1} \mathrm{H}$ NMR (400 MHz, CD 3 OD) $\delta 7.43(\mathrm{~d}, J=16 \mathrm{~Hz}, 1 \mathrm{H}), 7.11(\mathrm{~s}, 1 \mathrm{H})$, $7.03-7.00(\mathrm{~m}, 1 \mathrm{H}), 6.78(\mathrm{~d}, J=8 \mathrm{~Hz}, 1 \mathrm{H}), 6.41(\mathrm{~d}, J=16 \mathrm{~Hz}, 1 \mathrm{H}), 3.87$ $(\mathrm{s}, 3 \mathrm{H}), 3.29(\mathrm{t}, J=8 \mathrm{~Hz}, 2 \mathrm{H}), 3.22(\mathrm{t}, J=8 \mathrm{~Hz}, 2 \mathrm{H}), 1.73-1.66(\mathrm{~m}, 2 \mathrm{H})$, $1.63(\mathrm{~s}, 2 \mathrm{H}), 1.44(\mathrm{~s}, 4 \mathrm{H}), 1.32-1.26(\mathrm{~m}, 4 \mathrm{H}), 1.14(\mathrm{~s}, 2 \mathrm{H}), 0.92(\mathrm{~s}$, $6 \mathrm{H}) .{ }^{13} \mathrm{C}$ NMR $\left(100 \mathrm{MHz}, \mathrm{CD}_{3} \mathrm{OD}\right) \delta 177.79,168.00,148.87,148.00$, $140.82,126.55,121.91,117.08,115.16,110.09,54.95,50.48,48.96$, 48.41, 48.28, 44.09, 43.78, 43.43, 36.40, 36.37, 32.47, 28.98, 28.60. $\mathrm{MS}[\mathrm{ESI}+] \mathrm{m} / \mathrm{z} 455[\mathrm{M}+1]^{+}$.

\subsubsection{2. (1r,3s, 5R, 7S)-3-amino- $N-(4-((E)-3-(4-h y d r o x y-3-$} methoxyphenyl)acrylamido)butyl)-5,7-dimethyladamantane-1carboxamide (3)

Synthesized from $17(89 \mathrm{mg}, 0.30 \mathrm{mmol})$ and $16(160 \mathrm{mg}$, $0.61 \mathrm{mmol})$ to afford 3 as green solid: $68 \mathrm{mg}(48 \%)$; $\mathrm{mp} 116-117^{\circ} \mathrm{C}$; ${ }^{1} \mathrm{H}$ NMR (400 MHz, CD $\left.{ }_{3} \mathrm{OD}\right) \delta 7.40(\mathrm{~d}, J=15.6 \mathrm{~Hz}, 1 \mathrm{H}), 7.05(\mathrm{~s}, 1 \mathrm{H})$, 6.98-6.95 (m, 1H), 6.73 (d, $J=8 \mathrm{~Hz}, 1 \mathrm{H}), 6.37$ (d, $J=15.6 \mathrm{~Hz}, 1 \mathrm{H})$, $3.82(\mathrm{~s}, 3 \mathrm{H}), 3.27-3.24(\mathrm{~m}, 2 \mathrm{H}), 3.18-3.15(\mathrm{~m}, 2 \mathrm{H}), 1.54-1.49(\mathrm{~m}$, $6 \mathrm{H}), 1.38-1.36(\mathrm{~m}, 4 \mathrm{H}), 1.24(\mathrm{~s}, 4 \mathrm{H}), 1.07(\mathrm{~s}, 2 \mathrm{H}), 0.86(\mathrm{~s}, 6 \mathrm{H}) .{ }^{13} \mathrm{C}$ NMR $\left(100 \mathrm{MHz}, \mathrm{CD}_{3} \mathrm{OD}\right) \delta 177.94,167.83,149.83,148.29,140.76$, 126.04, 122.02, 116.86, 115.46, 110.03, 54.92, 49.76, 49.12, 49.09, $48.47,44.22,44.09,43.91,38.77,38.63,32.46,28.76,26.53,26.44$. MS [ESI+] $m / z 470[\mathrm{M}+1]^{+}$. 


\subsubsection{General procedure for the intermediates 22-25}

A mixture of memantine hydrochloride (MEM, 1 equiv), $\mathrm{K}_{2} \mathrm{CO}_{3}$ ( 2 equiv), KI ( 1 equiv) and the appropriate intermediate (18-21, 1 equiv) in dry DMF $(2-5 \mathrm{~mL})$ was placed in a microwave $\left(140^{\circ} \mathrm{C}, 250\right.$ Psi, $100 \mathrm{~W}$ ) and left stirring for $1 \mathrm{~h}$. The solvent was removed under reduced pressure and the crude purified by chromatography on silica gel using dichloromethane/methanol/aqueous ammonia 33\% (9:1:0.2) as mobile phase.

\subsubsection{4. tert-butyl (3-(( $(1 r, 3 R, 5 S, 7 r)-3,5$-dimethyladamantan-1- yl)amino)propyl)carbamate (22)}

Synthesized from 18 [14] $(0.4 \mathrm{~g}, 1.2 \mathrm{mmol})$ to afford 22 as a pale oil: $0.24 \mathrm{~g}(59 \%) ;{ }^{1} \mathrm{H}$ NMR $\left(400 \mathrm{MHz}, \mathrm{CDCl}_{3}\right) \delta 5.34$ (br s, $\left.1 \mathrm{H}\right)$, $3.16-3.14(\mathrm{~m}, 2 \mathrm{H}), 2.65(\mathrm{t}, J=6.6 \mathrm{~Hz}, 2 \mathrm{H}), 2.09-2.07(\mathrm{~m}, 1 \mathrm{H})$, $1.67-1.64(\mathrm{~m}, 2 \mathrm{H}), 1.49(\mathrm{~s}, 2 \mathrm{H}), 1.38(\mathrm{~s}, 9 \mathrm{H}), 1.32-1.23(\mathrm{~m}, 8 \mathrm{H})$, $1.06-1.05(\mathrm{~m}, 2 \mathrm{H}), 0.78(\mathrm{~s}, 6 \mathrm{H})$.

\subsubsection{5. tert-butyl (4-(( $(1 r, 3 R, 5 S, 7 r)-3,5$-dimethyladamantan-1- yl) amino)butyl) carbamate (23)}

Synthesized from 19 [32] $(0.4 \mathrm{~g}, 1.5 \mathrm{mmol})$ to afford 23 as a pale oil: $0.35 \mathrm{~g}(87 \%) ;{ }^{1} \mathrm{H}$ NMR $\left(400 \mathrm{MHz}, \mathrm{CDCl}_{3}\right) \delta 5.32$ (br s, $\left.1 \mathrm{H}\right)$, $3.00-2.99(\mathrm{~m}, 2 \mathrm{H}), 2.63(\mathrm{t}, J=7.2 \mathrm{~Hz}, 2 \mathrm{H}), 2.06-2.04(\mathrm{~m}, 1 \mathrm{H})$, $1.59-1.55(\mathrm{~m}, 4 \mathrm{H}), 1.48-1.43(\mathrm{~m}, 2 \mathrm{H}), 1.37-1.28(\mathrm{~m}, 13 \mathrm{H}), 1.24-1.13$ $(\mathrm{m}, 4 \mathrm{H}), 1.02-1.01(\mathrm{~m}, 2 \mathrm{H}), 0.73(\mathrm{~s}, 6 \mathrm{H})$.

\subsubsection{6. tert-butyl (5-(((1r,3R,5S,7r)-3,5-dimethyladamantan-1- yl)amino)pentyl)carbamate (24)}

Synthesized from 20 [33] $(0.4 \mathrm{~g}, 1 \mathrm{mmol})$ to afford $\mathbf{2 4}$ as a pale oil: $0.22 \mathrm{~g}(55 \%) ;{ }^{1} \mathrm{H} \mathrm{NMR}\left(400 \mathrm{MHz}, \mathrm{CDCl}_{3}\right) \delta 5.31(\mathrm{br} \mathrm{s}, 1 \mathrm{H}), 3.11-3.09$ $(\mathrm{m}, 2 \mathrm{H}), 2.59(\mathrm{t}, J=7.4 \mathrm{~Hz}, 2 \mathrm{H}), 2.15-2.13(\mathrm{~m}, 1 \mathrm{H}), 1.54-1.42(\mathrm{~m}$, $15 \mathrm{H}), 1.40-1.25(\mathrm{~m}, 10 \mathrm{H}), 1.16-1.11(\mathrm{~m}, 2 \mathrm{H}), 0.85(\mathrm{~s}, 6 \mathrm{H})$.

\subsubsection{7. tert-butyl (6-(( $(1 r, 3 R, 5 S, 7 r)-3,5$-dimethyladamantan-1- yl)amino) hexyl) carbamate (25)}

Synthesized from 21 [34] $(0.6 \mathrm{~g}, 1.6 \mathrm{mmol})$ to afford 25 as a pale oil: $0.4 \mathrm{~g}(79 \%) ;{ }^{1} \mathrm{H} \mathrm{NMR}\left(400 \mathrm{MHz}, \mathrm{CDCl}_{3}\right) \delta 4.61$ (br s, $\left.1 \mathrm{H}\right)$, 2.99-2.97 (m, 2H), $2.48(\mathrm{t}, J=7.4 \mathrm{~Hz}, 2 \mathrm{H}), 2.03-2.02(\mathrm{~m}, 1 \mathrm{H})$, $1.41-1.32(\mathrm{~m}, 15 \mathrm{H}), 1.24-1.15(\mathrm{~m}, 12 \mathrm{H}), 1.01-1.00(\mathrm{~m}, 2 \mathrm{H}), 0.73(\mathrm{~s}$, $6 \mathrm{H})$.

\subsubsection{General procedure for the intermediates 26-29}

To an ice-cooled appropriate Boc-protected intermediate (22-25, 1 equiv) was added $\mathrm{HCl} 4 \mathrm{M}$ in dioxane $(4 \mathrm{~mL})$ and the reaction mixture was stirred at $0{ }^{\circ} \mathrm{C}$ for $15-20$ min under $\mathrm{N}_{2}$ atmosphere. The solvent was evaporated and the crude purified by flash chromatography on silica gel using dichloromethane/methanol/aqueous ammonia $33 \%$ $(8: 2: 0.4)$ affording desired intermediates as free bases.

\subsubsection{9. $N^{1}-((1 r, 3 R, 5 S, 7 r)-3,5$-dimethyladamantan-1-yl)propane-1,3- diamine (26)}

Synthesized from $22(0.24 \mathrm{~g}, 0.7 \mathrm{mmol})$ to afford 26 as a pale oil: $0.09 \mathrm{~g}(54 \%) ;{ }^{1} \mathrm{H}$ NMR (400 MHz, DMSO- $\left.d_{6}\right) \delta 3.94$ (br s, $\left.3 \mathrm{H}\right)$, $2.74-2.73(\mathrm{~m}, 2 \mathrm{H}) 2.59(\mathrm{t}, J=6.8 \mathrm{~Hz}, 2 \mathrm{H}), 2.06-2.04(\mathrm{~m}, 1 \mathrm{H})$, $1.57-1.50$ (m, 2H), 1.42-1.41 (m, 2H), 1.26-1.18 (m, 8H), 1.09-1.00 $(\mathrm{m}, 2 \mathrm{H}), 0.78$ (s, 6H).

\subsubsection{0. $N^{1}-((1 r, 3 R, 5 S, 7 r)-3,5$-dimethyladamantan-1-yl)butane-1,4- diamine (27)}

Synthesized from $23(0.35 \mathrm{~g}, 1 \mathrm{mmol})$ to afford $\mathbf{2 7}$ as a pale oil: $0.18 \mathrm{~g}(72 \%) ;{ }^{1} \mathrm{H}$ NMR $\left(400 \mathrm{MHz}, \mathrm{CDCl}_{3}\right) \delta 2.66-2.62(\mathrm{~m}, 5 \mathrm{H}), 2.53$ (t, $J=6.8 \mathrm{~Hz}, 2 \mathrm{H}), 2.06-2.03(\mathrm{~m}, 1 \mathrm{H}), 1.48-1.40(\mathrm{~m}, 6 \mathrm{H}), 1.26-1.17$ $(\mathrm{m}, 8 \mathrm{H}), 1.05-0.98(\mathrm{~m}, 2 \mathrm{H}), 0.74(\mathrm{~s}, 6 \mathrm{H})$.
4.1.21. $N^{1}-((1 r, 3 R, 5 S, 7 r)-3,5$-dimethyladamantan-1-yl)pentane-1,5diamine (28)

Synthesized from $24(0.22 \mathrm{~g}, 0.6 \mathrm{mmol})$ to afford $\mathbf{2 8}$ as a pale oil: $0.11 \mathrm{~g}(70 \%) ;{ }^{1} \mathrm{H}$ NMR $\left(400 \mathrm{MHz}, \mathrm{CDCl}_{3}\right) \delta 2.63(\mathrm{t}, J=7.1 \mathrm{~Hz}, 2 \mathrm{H})$, $2.52(\mathrm{t}, J=7.1 \mathrm{~Hz}, 2 \mathrm{H}), 2.07-2.06(\mathrm{~m}, 1 \mathrm{H}), 1.59$ (br s, 3H), 1.42-1.38 (m, 6H), 1.31-1.17 (m, 10H), 1.05-1.04 (m, 2H), 0.78 (s, 6H).

\subsubsection{2. $N^{1}-((1 r, 3 R, 5 S, 7 r)-3,5$-dimethyladamantan-1-yl)hexane-1,6- diamine (29)}

Synthesized from $25(0.4 \mathrm{~g}, 1.06 \mathrm{mmol})$ to afford 29 as a pale oil: $0.16 \mathrm{~g}(54 \%) ;{ }^{1} \mathrm{H}$ NMR $\left(400 \mathrm{MHz}, \mathrm{CDCl}_{3}\right) \delta 2.63(\mathrm{t}, J=7.2 \mathrm{~Hz}, 2 \mathrm{H})$, $2.52(\mathrm{t}, J=7.2 \mathrm{~Hz}, 2 \mathrm{H}), 2.38$ (br s, 3H), 2.08-2.07 (m, 1H), 1.44-1.38 (m, 6H), 1.30-1.19 (m, 12H), 1.06-1.05 (m, 2H), 0.78 (s, 6H).

\subsubsection{General procedure for compounds 4-7}

To an ice-cooled solution of FA (1 equiv) in dry DMF $(3-4 \mathrm{~mL})$ was added HOBt (1.3 equiv) and EDC (1.3 equiv) under $\mathrm{N}_{2}$ atmosphere. The reaction mixture was stirred for 10 min at $0^{\circ} \mathrm{C}$, followed by addition of $\mathrm{Et}_{3} \mathrm{~N}$ (1.3 equiv) and the appropriate amine (26-29) (1 equiv). Stirring was then continued at room temperature overnight, then the solvent was evaporated under reduced pressure and the crude purified by chromatography on silica gel.

4.1.24. (E)-N-(3-(((1r,3R,5S,7r)-3,5-dimethyladamantan-1-

yl)amino)propyl)-3-(4-hydroxy-3-methoxyphenyl)acrylamide (4)

Synthesized from $26(90 \mathrm{mg}, 0.38 \mathrm{mmol})$, purified by chromatography on silica gel using petroleum ether/dichloromethane/methanol/ aqueous ammonia $33 \%(2: 6.5: 1.5: 0.16)$ as mobile phase to afford 4 as a yellow solid: $61.5 \mathrm{mg}(39 \%)$; mp $213-215^{\circ} \mathrm{C}$; ${ }^{1} \mathrm{H}$ NMR $(400 \mathrm{MHz}$, $\left.\mathrm{CDCl}_{3}\right) \delta 7.66($ br s, $1 \mathrm{H}), 7.49(\mathrm{~d}, J=15.6 \mathrm{~Hz}, 1 \mathrm{H}), 7.09(\mathrm{~s}, 1 \mathrm{H})$, 7.08-7.04 (m, 1H), $6.88(\mathrm{~d}, J=8 \mathrm{~Hz}, 1 \mathrm{H}), 6.64(\mathrm{~d}, J=15.6 \mathrm{~Hz}, 1 \mathrm{H})$, $3.90(\mathrm{~s}, 3 \mathrm{H}), 3.57-3.52(\mathrm{~m}, 2 \mathrm{H}), 2.94-2.91(\mathrm{~m}, 2 \mathrm{H}), 2.24(\mathrm{~m}, 3 \mathrm{H})$, $1.89-1.88(\mathrm{~m}, 2 \mathrm{H}), 1.72-1.63(\mathrm{~m}, 4 \mathrm{H}), 1.43-1.32(\mathrm{~m}, 4 \mathrm{H}), 1.20(\mathrm{~s}$, $2 \mathrm{H}), 0.85(\mathrm{~s}, 6 \mathrm{H}) .{ }^{13} \mathrm{C} \mathrm{NMR}\left(100 \mathrm{MHz}, \mathrm{CDCl}_{3}\right) \delta 167.60,147.53$, $147.02,140.33,127.35,122.15,119.07,114.87,110.05,59.04,56.03$, 49.88, 44.16, 41.92, 39.60, 38.59, 37.00, 32.57, 29.67, 26.77, 24.06. $\mathrm{MS}[\mathrm{ESI}+] \mathrm{m} / \mathrm{z} 413[\mathrm{M}+1]^{+}$.

4.1.25. (E)-N-(4-(( $1 r, 3 R, 5 S, 7 r)-3,5$-dimethyladamantan-1yl)amino)butyl)-3-(4-hydroxy-3-methoxyphenyl)acrylamide (5)

Synthesized from $27(72.5 \mathrm{mg}, 0.28 \mathrm{mmol})$, purified by chromatography on silica gel using petroleum ether/dichloromethane/methanol/ aqueous ammonia $33 \%(2: 6.5: 1.5: 0.07)$ as mobile phase to afford $\mathbf{5}$ as a yellow solid: $39.6 \mathrm{mg}$ (32\%); mp $174-175^{\circ} \mathrm{C}$; ${ }^{1} \mathrm{H}$ NMR $(400 \mathrm{MHz}$, $\left.\mathrm{CDCl}_{3}\right) \delta 7.83$ (br s, $\left.1 \mathrm{H}\right), 7.41(\mathrm{~d}, J=15.6 \mathrm{~Hz}, 1 \mathrm{H}), 7.04(\mathrm{~s}, 1 \mathrm{H}), 6.95$ $(\mathrm{d}, J=8.2 \mathrm{~Hz}, 1 \mathrm{H}), 6.86(\mathrm{~d}, J=8.2 \mathrm{~Hz}, 1 \mathrm{H}), 6.70(\mathrm{~d}, J=15.6 \mathrm{~Hz}, 1 \mathrm{H})$, $3.81(\mathrm{~s}, 3 \mathrm{H}), 3.33-3.32(\mathrm{~m}, 2 \mathrm{H}), 2.82(\mathrm{t}, J=7.4 \mathrm{~Hz}, 2 \mathrm{H}), 2.17(\mathrm{~s}, 1 \mathrm{H})$, $1.89-1.88(\mathrm{~m}, 4 \mathrm{H}), 1.71-1.62(\mathrm{~m}, 4 \mathrm{H}), 1.37-1.23(\mathrm{~m}, 6 \mathrm{H}), 1.14(\mathrm{~s}$, $2 \mathrm{H}), 0.84(\mathrm{~s}, 6 \mathrm{H}) .{ }^{13} \mathrm{C} \mathrm{NMR}\left(100 \mathrm{MHz}, \mathrm{CDCl}_{3}\right) \delta 167.60,147.53$, $147.02,140.33,127.35,122.15,119.07,114.87,110.05,59.04,56.03$, 49.88, 44.16, 41.92, 39.60, 38.59, 37.00, 32.57, 29.67, 26.77, 24.06. MS [ESI+] $m / z 427[\mathrm{M}+1]^{+}$.

\subsubsection{6. (E)-N-(5-(( $1 r, 3 R, 5 S, 7 r)-3,5$-dimethyladamantan-1-}

yl) amino)pentyl)-3-(4-hydroxy-3-methoxyphenyl)acrylamide (6)

Synthesized from 28 ( $54 \mathrm{mg}, 0.2 \mathrm{mmol})$, purified by chromatography on silica gel using petroleum ether/dichloromethane/methanol/ aqueous ammonia $33 \%(2: 6.5: 1.5: 0.09)$ as mobile phase to afford 6 as a yellow solid: $27.7 \mathrm{mg}$ (31\%); mp $200-202{ }^{\circ} \mathrm{C}$; ${ }^{1} \mathrm{H}$ NMR $(400 \mathrm{MHz}$, $\left.\mathrm{CDCl}_{3}\right) \delta 7.51(\mathrm{~d}, J=15.6 \mathrm{~Hz}, 1 \mathrm{H}), 7.03(\mathrm{~d}, J=7.6 \mathrm{~Hz}, 1 \mathrm{H}), 6.96$ $(\mathrm{s}, 1 \mathrm{H}), 6.86(\mathrm{~d}, J=7.6 \mathrm{~Hz}, 1 \mathrm{H}), 6.31(\mathrm{~d}, J=15.6 \mathrm{~Hz}, 1 \mathrm{H}), 5.82(\mathrm{br}$ $\mathrm{s}, 1 \mathrm{H}), 3.86(\mathrm{~s}, 3 \mathrm{H}), 3.37-3.33(\mathrm{~m}, 2 \mathrm{H}), 2.61(\mathrm{t}, J=7.2 \mathrm{~Hz}$, 
2H), 2.13-2.11 (m, 1H), 1.58-1.53 (m, 4H), 1.36-1.24 (m, 12H), 1.10-1.09 (m, 2H), $0.82(\mathrm{~s}, 6 \mathrm{H}),{ }^{13} \mathrm{C}$ NMR $\left(100 \mathrm{MHz}, \mathrm{CDCl}_{3}\right) \delta$ $166.21,147.43,146.81,140.72,127.33,121.93,118.40,114.84$, $109.72,55.86,50.83,48.43,42.89,40.83,40.37,39.52,32.37,30.24$, $30.19,29.45,24.78$. MS [ESI+] $\mathrm{m} / z 441[\mathrm{M}+1]^{+}$.

\subsubsection{7. (E)-N-(6-(( $1 r, 3 R, 5 S, 7 r)-3,5$-dimethyladamantan-1-}

yl)amino)hexyl)-3-(4-hydroxy-3-methoxyphenyl)acrylamide (7)

Synthesized from $29(0.1 \mathrm{~g}, 0.36 \mathrm{mmol})$, purified by chromatography on silica gel using petroleum ether/dichloromethane/methanol/ aqueous ammonia $33 \%(2: 6.5: 1.5: 0.1)$ as mobile phase to afford 7 as a yellow solid: $95.9 \mathrm{mg}(59 \%)$; mp $203-204{ }^{\circ} \mathrm{C}$; ${ }^{1} \mathrm{H} \mathrm{NMR}(400 \mathrm{MHz}$, $\left.\mathrm{CDCl}_{3}\right) \delta 7.51(\mathrm{~d}, J=15.2 \mathrm{~Hz}, 1 \mathrm{H}), 7.03(\mathrm{~d}, J=8.4 \mathrm{~Hz}, 1 \mathrm{H}), 6.97(\mathrm{~s}$, $1 \mathrm{H}), 6.86(\mathrm{~d}, J=8.4 \mathrm{~Hz}, 1 \mathrm{H}), 6.25$ (d, $J=15.2 \mathrm{~Hz}, 1 \mathrm{H}), 5.73$ (br s, $1 \mathrm{H})$, $3.88(\mathrm{~s}, 3 \mathrm{H}), 3.36-3.31(\mathrm{~m}, 2 \mathrm{H}), 2.57(\mathrm{t}, J=7.4 \mathrm{~Hz}, 2 \mathrm{H}), 2.12-2.09$ $(\mathrm{m}, 1 \mathrm{H}), 1.54-1.45(\mathrm{~m}, 6 \mathrm{H}), 1.33-1.23(12 \mathrm{H}), 1.13-1.05(\mathrm{~m}, 2 \mathrm{H})$, $0.82(\mathrm{~s}, 6 \mathrm{H}) .{ }^{13} \mathrm{C} \mathrm{NMR}\left(100 \mathrm{MHz}, \mathrm{CDCl}_{3}\right) \delta 166.20,147.57,146.90$, $140.74,127.26,121.96,118.35,114.90,109.75,55.85,50.85,48.42$, $42.90,40.79,40.45,39.54,32.37,30.24,30.20,29.50,27.03,26.73$. MS [ESI+] $m / z 455[\mathrm{M}+1]^{+}$.

\subsection{Electrophysiological assays}

Inhibition of NMDARs by compounds 1-7 and memantine was assessed by the expression of GluN1-1a and GluN2A subunits in Xenopus oocytes followed by voltage clamp recording. Oocytes were obtained from the European Xenopus Resource Centre (University of Portsmouth, UK) directly following their removal from mature female Xenopus laevis according to UK Home Office guidelines. Sections of the ovary were cut into smaller pieces and treated with $1 \mathrm{mg} / \mathrm{mL}$ collagenase type 1A (Sigma-Aldrich) in $\mathrm{Ca}^{2+}$-free modified Barth's media containing $96 \mathrm{mM} \mathrm{NaCl}, 2 \mathrm{mM} \mathrm{KCl}, 1 \mathrm{mM} \mathrm{MgCl}_{2}$, $5 \mathrm{mM}$ HEPES, $2.5 \mathrm{mM}$ pyruvic acid, $0.5 \mathrm{mM}$ theophylline, $0.05 \mathrm{mg}$ / $\mathrm{mL}$ gentamicin, $\mathrm{pH} 7.5$, with shaking at $18^{\circ} \mathrm{C}$ for $40-60 \mathrm{~min}$, in order to separate them into individual defolliculated oocytes. The oocytes were then rinsed in $\mathrm{Ca}^{2+}$-free modified Barth's media multiple times until the solution was clear and stored in modified Barth's media (as per $\mathrm{Ca}^{2+}$-free but including $1.8 \mathrm{mM} \mathrm{CaCl}_{2}$ ). Oocytes were injected with $50 \mathrm{~nL}$ of cRNA encoding both the GluN1-1a and GluN2A subunits $(1: 1$ by weight ratio; total $250 \mathrm{ng} / \mu \mathrm{L})$. The cRNA was synthesized from linearized plasmid DNA (pRK7) containing the GluN-encoding genes using an mMessage mMachine kit (Invitrogen). Following injection, oocytes were kept in modified Barth's media at $18^{\circ} \mathrm{C}$ for 3-4 days before electrophysiological testing. Voltage-clamp recording was conducted using an Axoclamp-2A voltage-clamp amplifier (Axon Instruments, USA). Microelectrodes were pulled from borosilicate glass capillaries (TW150F-4, World Precision Instruments) using a Sutter P-97 programmable micropipette puller to have a resistance of $0.5-2 \mathrm{M} \Omega$ when filled with $3 \mathrm{M} \mathrm{KCl}$. Oocytes were placed in a perfusion chamber and constantly perfused $(\sim 5 \mathrm{~mL} / \mathrm{min})$ with solution containing $96 \mathrm{mM} \mathrm{NaCl}, 2 \mathrm{mM} \mathrm{KCl}, 1.8 \mathrm{mM} \mathrm{CaCl}_{2}, 10 \mathrm{mM}$ HEPES, $\mathrm{pH} 7.5$, and voltage-clamped at holding potentials $\left(\mathrm{V}_{\mathrm{h}}\right)$ between -40 and $-100 \mathrm{mV}$. NMDAR currents were initiated by application of $100 \mu \mathrm{M}$ NMDA $+10 \mu \mathrm{M}$ glycine. Once the current had reached a steady state $(\sim 30 \mathrm{~s})$ the test compounds were introduced at concentrations ranging from 0.01 to $100 \mu \mathrm{M}$ until a new plateau (inhibited current) was achieved. All agonists and test compounds were applied using an Automate Valvelink 8 perfusion system. Analogue output from the amplifier was digitized by a CED 1401 plus A/D converter at $100 \mathrm{~Hz}$ and recorded on a windows PC using WinEDR software (Dr John Dempster, University of Strathclyde, UK). NMDA/ glycine-evoked current in the presence of test compound was normalized to that in its absence just before test compound addition (\% control response) and plotted against concentration. Concentration-inhibition data were fit by:

$$
\% \text { control response }=\frac{100}{1+10^{\left(\left(\log _{10} I C_{50}-X\right) \times \text { HillSlope }\right)}}
$$

to obtain $\mathrm{IC}_{50}$ values, where $\mathrm{X}=\log _{10}$ [compound]; using Graphpad Prism 7. All points were means of at least 5 separate oocytes. For voltage dependence studies the test compounds were applied at a single $\left(\sim \mathrm{IC}_{50}\right)$ concentration but at four $\mathrm{V}_{\mathrm{h}} \mathrm{S}$ in the range -40 to $-100 \mathrm{mV}$. Data were normalized as above and fit by:

$$
\% \text { control response }=\frac{100}{\left(1+\frac{[B]}{K_{D}}\right) e^{z \delta\left(\frac{F E}{R T}\right)}}
$$

to obtain $\delta$ values (fraction of the membrane electric field crossed by the blocking compound), where [B] is the concentration of the blocker, $K_{D}$ is the dissociation constant at $0 \mathrm{mV}, \mathrm{z}$ is the charge valence of the blocker, $\mathrm{F}$ is Faraday's constant, $\mathrm{E}$ is the membrane potential, $\mathrm{R}$ is the universal gas constant and $\mathrm{T}$ is absolute temperature; using Graphpad Prism 7. All points were means of at least 5 separate oocytes.

\subsection{Reagents for cellular experiments (SH-SY5Y cells)}

All hybrid compounds were solubilized in DMSO (at stock concentrations) and frozen $\left(-20^{\circ} \mathrm{C}\right)$ in aliquots that were diluted immediately prior to use. For each experimental setting, one stock aliquot was thawed out and diluted to minimize compound damage due to repeated freeze and thaw cycles. The final concentration of DMSO in culture medium was $<0.1 \%$. Ferulic Acid was purchased from Sigma Aldrich (Merck KGaA, Darmstadt, Germany). Rabbit polyclonal anti-human HO-1 (NBP1-31341) antibody was purchased from Novus (Biotechne, Minneapolis USA). Mouse monoclonal anti- $\beta$-tubulin (T0198) was purchased from by Sigma Aldrich (Merck KGaA, Darmstadt, Germany).

\subsection{Cell cultures}

All culture media, supplements and Foetal Bovine Serum (FBS) were purchased from Sigma Aldrich (Merck KGaA, Darmstadt, Germany). Human neuroblastoma SH-SY5Y cells from the European Collection of Cell Cultures (ECACC No. 94030304) were cultured in a medium with equal amounts of Eagle's minimum essential medium and Nutrient Mixture Ham's F-12, supplemented with 10\% heat-inactivated FBS, $2 \mathrm{mM}$ glutamine, $0.1 \mathrm{mg} / \mathrm{mL}$ streptomycin, $100 \mathrm{IU} \cdot \mathrm{mL}$ penicillin and non-essential aminoacids at $37^{\circ} \mathrm{C}$ in $5 \% \mathrm{CO}_{2}$ and $95 \%$ air atmosphere. H4-SW cells were cultured in D-MEM medium (Invitrogen, Carlsbad, CA) supplemented with $10 \%$ fetal bovine serum (FBS), $100 \mathrm{U} / \mathrm{mL}$ penicillin, $100 \mu \mathrm{g} / \mathrm{mL}$ streptomycin and $2 \mathrm{mM} \mathrm{L-glu-}$ tamine. Hygromycin B and Blasticidin S were used as selection antibiotics for SW mutation maintenance.

\subsection{Cell viability}

The mitochondrial dehydrogenase activity that reduces 3-(4,5-dimethylthiazol-2-yl)-2,5-diphenyl-tetrazolium bromide (MTT, Sigma Aldrich, Merck KGaA, Darmstadt, Germany) was used to determine 
cellular viability, in a quantitative colorimetric assay. At day 0 , SH-SY5Y cells were plated at a density of $2.5 \times 10^{4}$ viable cells per well in 96-well plates. After treatment, according to the experimental setting, cells were exposed to an MTT solution in complete medium $(1 \mathrm{mg} / \mathrm{mL})$. Following $4 \mathrm{~h}$ incubation with MTT and treatment with sodium dodecyl sulfate (SDS) for $24 \mathrm{~h}$, cell viability reduction was quantified by using a Synergy HT multidetection microplate reader (Bio-Tek).

\subsection{Measurement of intracellular ROS}

DCFH-DA (Sigma Aldrich, Merck KGaA, Darmstadt, Germany) was used to estimate intracellular ROS following two different experimental setting described in each figure legend. In each setting, cells were loaded with $25 \mu \mathrm{M}$ DCFH-DA for $45 \mathrm{~min}$. After centrifugation DCFH-DA was removed, and the results were visualized using Synergy HT multidetection microplate reader (BioTek) with excitation and emission wavelengths of 485 and $530 \mathrm{~nm}$, respectively.

\subsection{Real-time PCR (RT-PCR)}

For RNA extraction, $2 \times 10^{6}$ cells were used. Total RNA was extracted using a Direct-zol ${ }^{\mathrm{TM}}$ RNA MiniPrep (Zymo Research, Irvine, USA) following the manufacturer's instructions. QuantiTect reversion transcription kit and QuantiTect Sybr Green PCR kit (Qiagen, Valencia, CA, USA) were used for cDNA synthesis and gene expression analysis, following the manufacturer's specifications. Nrf2, HO-1, and GAPDH primers were provided by Qiagen. GAPDH was used as an endogenous reference.

\subsection{Immunodetection of HO-1, flAPP and SAPP $\boldsymbol{\alpha}$}

The expression of HO-1 in whole cell lysates was assessed by Western blot analysis. After treatment, cell monolayers were washed twice with ice-cold PBS, lysed on the culture dish by the addition of ice-cold homogenization buffer $(50 \mathrm{mM}$ Tris- $\mathrm{HCl} \mathrm{pH} 7.4,150 \mathrm{mM}$ $\mathrm{NaCl}, 5 \mathrm{mM}$ EDTA, $0.5 \%$ Triton $\mathrm{X}-100$ and protease inhibitor mix) and an aliquot was used for protein quantification, whereas the remainder was prepared for Western blot by mixing the cell lysate with $2 \mathrm{X}$ sample buffer $(125 \mathrm{mM}$ Tris- $\mathrm{HCl} \mathrm{pH}$ 6.8, 4\% SDS, 20\% glycerol, $6 \% \beta$-mercaptoethanol, $0.1 \%$ bromophenol blue) and then denaturing at $95^{\circ} \mathrm{C}$ for $5 \mathrm{~min}$. Equivalent amounts of extracted proteins were loaded into a SDS-PAGE gel, electrophoresed under reducing conditions, transferred to a PVDF membrane (Sigma Aldrich, Merck KGaA, Darmstadt, Germany) and then blocked for $1 \mathrm{~h}$ with $5 \% \mathrm{w} /$ $\mathrm{v}$ BSA in Tris-buffered saline containing $0.1 \%$ Tween 20 (TBS-T). The proteins were visualized using primary antibodies for $\mathrm{HO}-1$, full length (fl) APP or soluble APP alpha $(\operatorname{sAPP} \alpha)$ and $\alpha$ - or $\beta$-tubulin $(1: 1000)$ followed by secondary horseradish peroxidase conjugated antibody (1:5000) diluted in 5\% w/v BSA in TBS-T. Tubulins were performed as a control for gel loading. Signal development was carried out using an enhanced chemiluminescent method (Pierce, Rockford, IL, USA).

\subsection{Densitometry and statistics}

All experiments, unless specified, were performed at least three times with representative results being shown. Data are expressed as mean \pm SEM. The relative densities of the acquired images of Western blotting bands were analyzed with ImageJ software. Statistical analyses were performed using Prism software version 7.0 (GraphPad Software, La Jolla, CA, USA). Statistical differences were determined by analysis of variance (ANOVA) followed, when significant, by an appropriate post hoc test as indicated in figure legends. A $\mathrm{p}$ value of $<0.05$ was considered statistically significant.

\section{Acknowledgments}

This work was supported by the University of Bologna (grants from the RFO).

\section{Appendix A. Supplementary data}

Supplementary data to this article can be found online at https:// doi.org/10.1016/j.ejmech.2019.07.011.

\section{References}

[1] H. Niu, I. Álvarez-Álvarez, F. Guillén-Grima, I. Aguinaga-Ontoso, Prevalence and incidence of Alzheimer's disease in Europe: a meta-analysis, Neurologia 32 (8) (2017) 523-532.

[2] S.F. Traynelis, L.P. Wollmuth, C.J. McBain, et al., Glutamate receptor ion channels: structure, regulation, and function, Pharmacol. Rev. 62 (3) (2010) 405-496.

[3] M.K. Müller, E. Jacobi, K. Sakimura, R. Malinow, J. von Engelhardt, NMDA receptors mediate synaptic depression, but not spine loss in the dentate gyrus of adult amyloid Beta (A $\beta$ ) overexpressing mice, Acta Neuropathol Commun 6 (1) (2018) 110.

[4] G.E. Hardingham, Y. Fukunaga, H. Bading, Extrasynaptic NMDARs oppose synaptic NMDARs by triggering CREB shut-off and cell death pathways, Nat. Neurosci. 5 (5) (2002) 405-414.

[5] S.A. Lipton, NMDA receptor activity regulates transcription of antioxidant pathways, Nat. Neurosci. 11 (4) (2008) 381-382.

[6] C. Lanni, F. Fagiani, M. Racchi, et al., Beta-amyloid short- and long-term synaptic entanglement, Pharmacol. Res. 139 (2019) 243-260.

[7] S. Tu, S. Okamoto, S.A. Lipton, H. Xu, Oligomeric A $\beta$-induced synaptic dysfunction in Alzheimer's disease, Mol. Neurodegener. 9 (2014) 48.

[8] P. Xia, H.S. Chen, D. Zhang, S.A. Lipton, Memantine preferentially blocks extrasynaptic over synaptic NMDA receptor currents in hippocampal autapses, J. Neurosci. 30 (33) (2010) 11246-11250.

[9] X. Song, M. Jensen, V. Jogini, et al., Mechanism of NMDA receptor channel block by MK-801 and memantine, Nature 556 (7702) (2018) 515-519.

[10] H. Takahashi, P. Xia, J. Cui, et al., Pharmacologically targeted NMDA receptor antagonism by NitroMemantine for cerebrovascular disease, Sci. Rep. 5 (2015) 14781

[11] C.P. Figueiredo, J.R. Clarke, J.H. Ledo, et al., Memantine rescues transient cognitive impairment caused by high-molecular-weight a $\beta$ oligomers but not the persistent impairment induced by low-molecular-weight oligomers, J. Neurosci. 33 (23) (2013) 9626-9634.

[12] M. Benchekroun, A. Romero, J. Egea, et al., The antioxidant additive approach for Alzheimer's disease therapy: new ferulic (Lipoic) acid plus melatonin modified tacrines as cholinesterases inhibitors, direct antioxidants, and nuclear factor (Erythroid-Derived 2)-like 2 Activators, J. Med. Chem. 59 (21) (2016) 9967-9973.

[13] S.A. Lipton, Paradigm shift in neuroprotection by NMDA receptor blockade: memantine and beyond, Nat. Rev. Drug Discov. 5 (2) (2006) 160-170.

[14] E. Simoni, S. Daniele, G. Bottegoni, et al., Combining galantamine and memantine in multitargeted, new chemical entities potentially useful in Alzheimer's disease, J. Med. Chem. 55 (22) (2012) 9708-9721.

[15] A.M. Reggiani, E. Simoni, R. Caporaso, et al., In vivo characterization of ARN14140, a memantine/galantamine-based multi-target compound for Alzheimer's disease, Sci. Rep. 6 (2016) 33172.

[16] E. Minniti, J.A.W. Byl, L. Riccardi, et al., Novel xanthone-polyamine conjugates as catalytic inhibitors of human topoisomerase II $\alpha$, Bioorg. Med. Chem. Lett 27 (20) (2017) 4687-4693.

[17] E. Riva, D. Comi, S. Borrelli, et al., Synthesis and biological evaluation of new camptothecin derivatives obtained by modification of position 20, Bioorg. Med. Chem. 18 (24) (2010) 8660-8668.

[18] L. Wanka, C. Cabrele, M. Vanejews, P. Schreiner, gamma-aminoadamantanecarboxylic acids through direct C-H bond amidations, Eur. J. Org. Chem. (9) (2007) 1474-1490.

[19] A. Sobolevsky, S. Koshelev, B. Khodorov, Probing of NMDA channels with fast blockers, J. Neurosci. 19 (24) (1999) 10611-10626.

[20] A.M. Woodhull, Ionic blockage of sodium channels in nerve, J. Gen. Physiol. 61 (6) (1973) 687-708. 
[21] A. Cuadrado, A.I. Rojo, G. Wells, et al., Therapeutic targeting of the NRF2 and KEAP1 partnership in chronic diseases, Nat. Rev. Drug Discov. 18 (4) (2019) 295-317.

[22] A.T. Dinkova-Kostova, R.V. Kostov, P. Canning, Keap1, the cysteine-based mammalian intracellular sensor for electrophiles and oxidants, Arch. Biochem. Biophys. 617 (2017) 84-93.

[23] F. Basagni, C. Lanni, A. Minarini, M. Rosini, Lights and shadows of electrophile signaling: focus on the Nrf2-Keap1 pathway, Future Med. Chem. 11 (7) (2019) 707-721.

[24] E. Simoni, M.M. Serafini, R. Caporaso, et al., Targeting the Nrf2/amyloid-beta Liaison in Alzheimer's disease: a rational approach, ACS Chem. Neurosci. 8 (7) (2017) 1618-1627.

[25] E. Simoni, C. Bergamini, R. Fato, et al., Polyamine conjugation of curcumin analogues toward the discovery of mitochondria-directed neuroprotective agents, J. Med. Chem. 53 (19) (2010) 7264-7268.

[26] K. Bordji, J. Becerril-Ortega, O. Nicole, A. Buisson, Activation of extrasynaptic, but not synaptic, NMDA receptors modifies amyloid precursor protein expression pattern and increases amyloid- $\beta$ production, J. Neurosci. 30 (47) (2010) $15927-15942$

[27] J. Folch, O. Busquets, M. Ettcheto, et al., Memantine for the treatment of dementia: a review on its current and future applications, J. Alzheimer's Dis. 62 (3) (2018) 1223-1240.
[28] G.M. Alley, J.A. Bailey, D. Chen, et al., Memantine lowers amyloid-beta peptide levels in neuronal cultures and in APP/PS1 transgenic mice, J. Neurosci. Res. 88 (1) (2010) 143-154.

[29] K. Bordji, J. Becerril-Ortega, A. Buisson, Synapses, NMDA receptor activity and neuronal A $\beta$ production in Alzheimer's disease, Rev. Neurosci. 22 (3) (2011) 285-294.

[30] A. Habib, D. Sawmiller, J. Tan, Restoring soluble amyloid precursor protein $\alpha$ functions as a potential treatment for Alzheimer's disease, J. Neurosci. Res. 95 (4) (2017) 973-991.

[31] G. Palermo, E. Minniti, M. Greco, et al., An optimized polyamine moiety boosts the potency of human type II topoisomerase poisons as quantified by comparative analysis centered on the clinical candidate F14512, Chem. Commun. 51 (76) (2015) 14310-14313.

[32] C. Nguyen, G.F. Ruda, A. Schipani, et al., Acyclic nucleoside analogues as inhibitors of Plasmodium falciparum dUTPase, J. Med. Chem. 49 (14) (2006) 4183-4195.

[33] G. Lamanna, C. Smulski, N. Chekkat, et al., Multimerization of an Apoptogenic TRAIL-mimicking peptide by using adamantane-based dendrons, Chemistry-a European Journal 19 (5) (2013) 1762-1768.

[34] V. Zanichelli, M. Bazzoni, A. Arduini, et al., Redox-switchable calix[6]arene-based isomeric rotaxanes, Chemistry 24 (47) (2018) 12370-12382. 